\title{
Silylene Transfer to Carbonyl Compounds and Subsequent Ireland-Claisen Rearrangements to Control Formation of Quaternary Carbon Stereocenters
}

\author{
Stacie A. Calad and K. A. Woerpel* \\ Department of Chemistry, University of California, \\ Irvine, California 92697-2025
}

\section{Contents:}

\section{Supporting Information}

I. Silver-catalyzed Silylene Transfer to Esters and Ketones...................

II. Ireland-Claisen Rearrangements and Utility of Products......................S-5

III. Aldol Reactions of Intermediate Oxasilacyclopentenes.......................S-7

IV. Stereochemical Assignment of Aldol products..............................

V. References.....................................................

VI. X-ray Crystallographic Data.......................................S-10

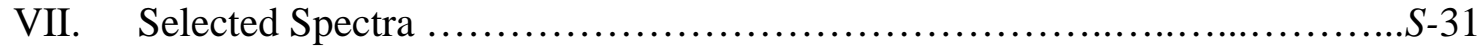

\section{Experimental Section}

General. Melting points were obtained using a Büchi 510 melting point apparatus and are reported uncorrected. Analytical gas chromatography (GC) was performed using an Agilent 6850 series chromatograph, equipped with an Agilent 6850 auto sampler and a flame ionization detector. A fused silica capillary column (30 m x $0.32 \mathrm{~mm} \times 0.25 \mu \mathrm{m}$ ) wall-coated with HP-1 (J \& W Scientific) was used with helium as the carrier gas. Analytical thin layer chromatography was performed on EM reagents $0.25 \mathrm{~mm}$ silica gel $60-\mathrm{F}$ plates. Liquid chromatography was performed using forced flow (flash chromatography) of the indicated solvent system on EM reagents silica gel $\left(\mathrm{SiO}_{2}\right) 60(230-400)$ mesh or on Aldrich Davasil ${ }^{\circledR}$ silica gel $\left(\mathrm{SiO}_{2}\right)$ as indicated. ${ }^{1} \mathrm{H}$ NMR and ${ }^{13} \mathrm{C}$ NMR spectra were recorded at $25{ }^{\circ} \mathrm{C}$ at 400 and 100 , and 500 and $125 \mathrm{MHz}$, respectively, using Bruker DRX 400 or DRX 500 spectrometers, as indicated. The data are reported as follows: chemical shift in ppm from internal tetramethylsilane on the $\delta$ scale, multiplicity $(\mathrm{br}=$ broad, $\mathrm{s}=$ singlet, $\mathrm{d}=$ doublet, $\mathrm{t}=$ triplet, $\mathrm{q}$ $=$ quartet, $\mathrm{p}=$ pentet, $\mathrm{m}=$ multiplet), coupling constants $(\mathrm{Hz})$, and integration. The ${ }^{29} \mathrm{Si}$ NMR chemical shifts are reported in ppm from tetramethylsilane on the $\delta$ scale, using tetramethylsilane as an external standard. High resolution mass spectra were acquired on a VG Analytical 7070E or Fisons Autospec spectrometer, and were obtained by peak matching. Microanalyses were performed by Atlantic Microlabs, Atlanta, GA or Desert Analytics, Tucson, AZ. Silacyclopropanes and oxasilacyclopentenes (where indicated) were stored and manipulated in an Innovative Technologies nitrogen-atmosphere dry box. All reactions were performed under an atmosphere of nitrogen or Argon in glassware that had been flame-dried under a stream of nitrogen or under vacuum. Solvents were distilled or filtered before use. Cyclohexenesilacyclopropane (2) was constructed by known methods. ${ }^{1,2}$

\section{Silver-catalyzed Silylene Transfer to Esters and Ketones}

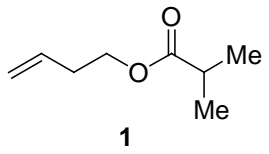




\section{Isobutyric Acid But-3-enyl Ester (1). ${ }^{3}$}

To a cooled solution $\left(0^{\circ} \mathrm{C}\right)$ of 4 -(dimethylamino)pyridine $(0.0190 \mathrm{~g}, 0.155 \mathrm{mmol})$ in $4 \mathrm{~mL}$ of pyridine was added 3-buten-1-ol (0.735 mL, $8.54 \mathrm{mmol})$. Isobutyryl chloride $(0.980 \mathrm{~mL}, 9.39 \mathrm{mmol})$ was added dropwise to the stirred solution. After $6.5 \mathrm{~h}$, the white opaque mixture was poured into $50 \mathrm{~mL}$ of $\mathrm{H}_{2} \mathrm{O}$ and the aqueous layer was extracted with $2 \times 50 \mathrm{~mL}$ of $\mathrm{Et}_{2} \mathrm{O}$. The combined organic layers were washed with $2 \times 50 \mathrm{~mL}$ of saturated $\mathrm{NH}_{4} \mathrm{Cl}, 2 \times 50 \mathrm{~mL}$ of $\mathrm{H}_{2} \mathrm{O}$, and $50 \mathrm{~mL}$ of brine. The resulting organic phase was dried $\left(\mathrm{MgSO}_{4}\right)$, filtered, and concentrated in vacuo. Purification by flash chromatography (20:1 pentane:Et ${ }_{2} \mathrm{O}$ ) afforded the product as a clear oil (0.885 g, 73\%): ${ }^{1} \mathrm{H} \mathrm{NMR}\left(\mathrm{CDCl}_{3}, 500 \mathrm{MHz}\right) \delta 5.80$ (tdd, $\left.J=6.8,10.3,17.1,1 \mathrm{H}\right), 5.12(\mathrm{qd}, J=1.6$, 17.2, 1H), 5.08 (qd, $J=1.2,10.2,1 \mathrm{H}), 4.13$ (t, $J=6.7,2 \mathrm{H}), 2.54$ (septet, $J=7.0,1 \mathrm{H}), 2.40$ (td, $J=1.4,6.7$, $1 \mathrm{H}), 2.37(\mathrm{td}, J=1.4,6.7,1 \mathrm{H}), 1.17(\mathrm{~d}, J=7.0,6 \mathrm{H}) ;{ }^{13} \mathrm{C} \mathrm{NMR}\left(\mathrm{CDCl}_{3}, 125 \mathrm{MHz}\right) \delta 177.3,134.3,117.3,63.4$, 34.2, 33.3, 19.2; IR (thin film) 3082, 2976, 1737, 1193, $1158 \mathrm{~cm}^{-1}$; HRMS (EI) $\mathrm{m} / \mathrm{z}$ calcd for $\mathrm{C}_{8} \mathrm{H}_{14} \mathrm{O}_{2}\left(\mathrm{M}^{+}\right)$ 142.0994, found 142.0992.

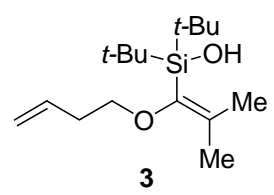

Vinyl Silanol (3). To a solution of $\mathrm{AgOCOCF}_{3}(0.001 \mathrm{~g}, 0.005 \mathrm{mmol})$ in $0.35 \mathrm{~mL}$ of toluene was added isobutyrate $1(0.143 \mathrm{~g}, 1.00 \mathrm{mmol})$ in $2.0 \mathrm{~mL}$ of toluene followed by cyclohexene silacyclopropane 2 (0.240 g, $1.07 \mathrm{mmol}$ ) in $2.0 \mathrm{~mL}$ of toluene. After $1.5 \mathrm{~h}$, the mixture was poured into $30 \mathrm{~mL}$ of $\mathrm{NaHCO}_{3}$ (saturated, aq) and the aqueous layer was extracted with $3 \times 20 \mathrm{~mL}$ of $\mathrm{CH}_{2} \mathrm{Cl}_{2}$. The combined organic layers were washed with $30 \mathrm{~mL}$ of brine, dried $\left(\mathrm{NaSO}_{4}\right)$, filtered, and concentrated in vacuo. Flash chromatography (3:97 Et $\mathrm{O}_{2} \mathrm{O}$ : pentane) afforded the product $(0.128 \mathrm{~g}, 45 \%):{ }^{1} \mathrm{H} \mathrm{NMR}\left(\mathrm{CDCl}_{3}, 500 \mathrm{MHz}\right) \delta 5.75-5.84$ (tdd, $J=7.0,10.1,17.2$, 1H), 5.06 (d, $J=17.3,1 \mathrm{H}), 5.02$ (d, $J=10.2,1 \mathrm{H}), 3.47$ (t, $J=6.5,2 \mathrm{H}), 2.30(\mathrm{~m}, 2 \mathrm{H}), 1.68(\mathrm{~s}, 3 \mathrm{H}), 1.66(\mathrm{~s}, 3 \mathrm{H})$, 0.96 (s, 18H); ${ }^{13} \mathrm{C} \mathrm{NMR}\left(\mathrm{CDCl}_{3}, 125 \mathrm{MHz}\right) \delta 151.8,136.2,135.5,117.6,70.5,35.0,28.5,22.2,21.2,18.5 ;$ IR (thin film) 3520, 2933, 2858, 1473, 1095, $823 \mathrm{~cm}^{-1}$; HRMS (CI) $\mathrm{m} / \mathrm{z}$ calcd for $\mathrm{C}_{16} \mathrm{H}_{33} \mathrm{O}_{2} \mathrm{Si}(\mathrm{M}+\mathrm{H})^{+}$285.2251, found 285.2249. Anal. Calcd for $\mathrm{C}_{16} \mathrm{H}_{32} \mathrm{O}_{2} \mathrm{Si}$ : C, 67.54; H, 11.34. Found: C, 67.58; H, 11.60.

\section{Oxasilacyclopentene (7a).}

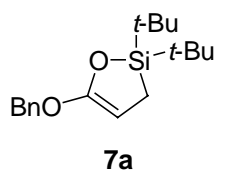

\section{Representative procedure for silver-catalyzed silylene transfer to $\alpha, \beta$-unsaturated esters:}

To a solution of $\mathrm{AgOCOCF}_{3}(0.003 \mathrm{~g}, 0.01 \mathrm{mmol})$ in $0.4 \mathrm{~mL}$ of a $0.0436 \mathrm{M}$ solution of $\mathrm{PhSi}\left(\mathrm{CH}_{3}\right)_{3}$ in $\mathrm{C}_{6} \mathrm{D}_{6}$ (contained in an NMR tube) was added benzyl acrylate $(0.039 \mathrm{~g}, 0.27 \mathrm{mmol})$. Cyclohexene silacyclopropane 2 (0.055 g, $0.24 \mathrm{mmol}$ ) was added to the reaction mixture in $0.4 \mathrm{~mL}$ of a $0.0436 \mathrm{M}$ solution of $\mathrm{PhSi}\left(\mathrm{CH}_{3}\right)_{3}$ in $\mathrm{C}_{6} \mathrm{D}_{6}$. After $20 \mathrm{~min},{ }^{1} \mathrm{H}$ NMR spectroscopy showed the disappearance of the starting silacyclopropane $t$-Bu peaks ( $\delta 1.20$ and $1.02 \mathrm{ppm})$, and the growth of peaks associated with the products: cyclohexene $(\delta 5.68 \mathrm{ppm})$ and the $t$-Bu peak of 7a $(\delta 1.02 \mathrm{ppm})$. The yield was found to be $98 \%$ through comparison of the area of the $\mathrm{PhSi}\left(\mathrm{CH}_{3}\right)_{3}$ peak $(\delta 0.19 \mathrm{ppm})$ and the area of the $t$-Bu peak in the product: ${ }^{1} \mathrm{H}$ NMR $\left(\mathrm{C}_{6} \mathrm{D}_{6}, 500 \mathrm{MHz}\right) \delta 7.10$ (m, 5H), $4.74(\mathrm{~s}, 2 \mathrm{H}), 4.00(\mathrm{t}, J=2.9,1 \mathrm{H}), 1.42(\mathrm{~d}, J=3.0,2 \mathrm{H}), 1.02(\mathrm{~s}, 18 \mathrm{H}) ;{ }^{13} \mathrm{C} \mathrm{NMR}\left(\mathrm{C}_{6} \mathrm{D}_{6}, 125 \mathrm{MHz}\right) \delta$ 163.7, 137.8, 132.0, 128.9, 128.0, 70.2, 70.0, 27.2, 20.7, 7.9; ${ }^{29} \mathrm{Si}$ NMR $\left(\mathrm{C}_{6} \mathrm{D}_{6}, 99.3 \mathrm{MHz}\right) \delta 35.7$.

\section{Procedure for isolation of oxasilacyclopentene (7a):}

This procedure was conducted in a drybox. To a solution of $\mathrm{AgOCOCF}_{3}(0.001 \mathrm{~g}, 0.005 \mathrm{mmol})$ in $5.0 \mathrm{~mL}$ of $\mathrm{CH}_{2} \mathrm{Cl}_{2}$ was added benzyl acrylate $(0.348 \mathrm{~g}, 2.35 \mathrm{mmol})$ followed by cylclohexene silacyclopropane 2 (0.501 g, 
$2.23 \mathrm{mmol}$ ) in $5.0 \mathrm{~mL}$ of $\mathrm{CH}_{2} \mathrm{Cl}_{2}$. After $3 \mathrm{~h}$, the solution was filtered through Celite 545 , rinsed with $\mathrm{CH}_{2} \mathrm{Cl}_{2}$, and concentrated in vacuo. The residue was dissolved in $5 \mathrm{~mL}$ of hexanes and extracted with $3 \times 3 \mathrm{~mL}$ of MeCN. The MeCN layers were combined and concentrated to an oily solid $(0.515$ g, $76 \%):{ }^{1} \mathrm{H}$ NMR $\left(\mathrm{C}_{6} \mathrm{D}_{6}\right.$, $400 \mathrm{MHz}) \delta 7.23(\mathrm{~d}, J=7.5,2 \mathrm{H}), 7.06(\mathrm{~m}, 3 \mathrm{H}), 4.75(\mathrm{~s}, 2 \mathrm{H}), 4.01(\mathrm{t}, J=3.1,1 \mathrm{H}), 1.43(\mathrm{~d}, J=3.1,2 \mathrm{H}), 1.03(\mathrm{~s}$, $18 \mathrm{H}) ;{ }^{13} \mathrm{C}$ NMR $\left(\mathrm{C}_{6} \mathrm{D}_{6}, 100 \mathrm{MHz}\right) \delta 163.7,137.8,128.9,128.7,128.0,70.3,70.0,27.2,20.7,7.9$; IR (thin film) 2933, 2859, 1636, 1140, $824 \mathrm{~cm}^{-1}$; HRMS (CI) $\mathrm{m} / \mathrm{z}$ calcd for $\mathrm{C}_{18} \mathrm{H}_{28} \mathrm{O}_{2} \mathrm{Si}(\mathrm{M})^{+} 304.1859$, found 304.1859. Anal. Calcd for $\mathrm{C}_{18} \mathrm{H}_{28} \mathrm{O}_{2} \mathrm{Si}$ : C, 71.00; H, 9.27. Found: C, 70.67; H, 9.11.

\section{Oxasilacyclopentene (7b).}

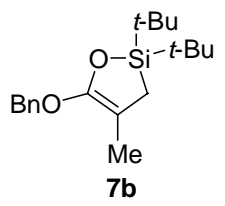

The representative procedure for silver-catalyzed silylene transfer to $\alpha, \beta$-unsaturated esters was followed using $\operatorname{AgOCOCF}_{3}(0.0004 \mathrm{~g}, 0.0016 \mathrm{mmol})$, benzyl methacrylate $(0.0273 \mathrm{~mL}, 0.161 \mathrm{mmol})$, and $2(0.0397 \mathrm{~g}, 0.177$ mmol). The yield (NMR) was found to be $93 \%$ after $40 \mathrm{~min}:{ }^{1} \mathrm{H}$ NMR $\left(\mathrm{C}_{6} \mathrm{D}_{6}, 500 \mathrm{MHz}\right) \delta 7.33(\mathrm{~d}, J=8.1$, 2H), 7.16 (m, 3H), 4.98 (s, 2H), 1.84 (s, 2H), 1.05 (s, 3H), 1.00 (s, 18H); ${ }^{13} \mathrm{C}$ NMR $\left(\mathrm{C}_{6} \mathrm{D}_{6}, 125 \mathrm{MHz}\right) \delta 155.5$, 138.8, 128.8, 128.3, 128.2, 83.7, 70.2, 27.2, 20.5, 15.2, 14.1; ${ }^{29}$ Si NMR $\left(\mathrm{C}_{6} \mathrm{D}_{6}, 99.3 \mathrm{MHz}\right) \delta 30.6$.

\section{Oxasilacyclopentene (7c).}

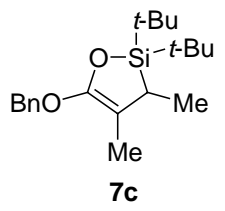

The representative procedure for silver-catalyzed silylene transfer to $\alpha, \beta$-unsaturated esters was followed using $\mathrm{AgOCOCF}_{3}(0.0004 \mathrm{~g}, 0.0016 \mathrm{mmol})$, benzyl tiglate $(0.0297 \mathrm{~mL}, 0.161 \mathrm{mmol})$, and $2(0.0397 \mathrm{~g}, 0.177 \mathrm{mmol})$. The yield (NMR) was found to be $99 \%$ after $50 \mathrm{~min}:{ }^{1} \mathrm{H}$ NMR $\left(\mathrm{C}_{6} \mathrm{D}_{6}, 500 \mathrm{MHz}\right) \delta 7.32(\mathrm{~m}, 2 \mathrm{H}), 7.14(\mathrm{~m}, 3 \mathrm{H})$, 4.97 (s, 2H), 1.34 (d, $J=6.9,1 \mathrm{H}), 1.18$ (d, $J=6.2,3 \mathrm{H}), 1.07$ (s, 9H), 1.03 (s, 3H), 0.98 (s, 9H); ${ }^{13} \mathrm{C}$ NMR $\left(\mathrm{C}_{6} \mathrm{D}_{6}, 125 \mathrm{MHz}\right) \delta 154.6,134.0,128.8,128.3,128.2,88.9,70.1,28.4,27.6,22.5,22.1,20.9,14.6,10.9 ;{ }^{29} \mathrm{Si}$ $\operatorname{NMR}\left(\mathrm{C}_{6} \mathrm{D}_{6}, 99.3 \mathrm{MHz}\right) \delta 27.7$.

\section{Oxasilacyclopentene (7d).}

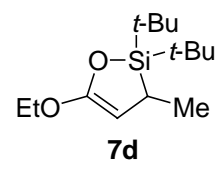

The representative procedure for silver-catalyzed silylene transfer to $\alpha, \beta$-unsaturated esters was followed using $\mathrm{AgOCOCF}_{3}(0.0004 \mathrm{~g}, 0.0016 \mathrm{mmol})$, ethyl trans-crotonate $(0.0210 \mathrm{~mL}, 0.172 \mathrm{mmol})$, and $2(0.0385 \mathrm{~g}, 0.172$ mmol). The yield (NMR) was found to be $98 \%$ after 75 min: ${ }^{1} \mathrm{H}$ NMR $\left(\mathrm{C}_{6} \mathrm{D}_{6}, 500 \mathrm{MHz}\right) \delta 3.79$ (d, $J=2.7$, $1 \mathrm{H}$ ), 3.61 (q, $J=7.0,2 \mathrm{H}), 2.16$ (dq, $J=2.7,7.5,1 \mathrm{H}), 1.30$ (d, $J=7.6,3 \mathrm{H}), 1.13$ (s, 9H), 1.05 (s, 9H), 0.99 (t, $J$ $=7.1,3 \mathrm{H}) ;{ }^{13} \mathrm{C}$ NMR $\left(\mathrm{C}_{6} \mathrm{D}_{6}, 125 \mathrm{MHz}\right) \delta 162.6,77.4,63.9,28.3,27.6,25.8,23.3,19.0,18.0,15.0 ;{ }^{29} \mathrm{Si}$ NMR $\left(\mathrm{C}_{6} \mathrm{D}_{6}, 99.3 \mathrm{MHz}\right) \delta 30.4$. 


\section{Oxasilacyclopentene (7e).}

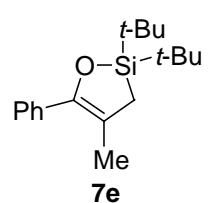

To a flask containing AgOCOCF $3(0.001 \mathrm{~g}, 0.005 \mathrm{mmol})$ was added isopropylidene phenyl ketone ${ }^{4}(0.038 \mathrm{~g}$, $0.26 \mathrm{mmol})$ in $0.5 \mathrm{~mL}$ of toluene followed by cyclohexene silacyclopropane $2(0.056 \mathrm{~g}, 0.25 \mathrm{mmol})$ in $0.5 \mathrm{~mL}$ of toluene. After $18 \mathrm{~h}$, the brown solution was diluted with $1.0 \mathrm{~mL}$ of pentane and concentrated in vacuo. Column chromatography (1:99 $\mathrm{Et}_{3} \mathrm{~N}$ :pentane) afforded the product as an oil $(0.051 \mathrm{~g}, 71 \%):{ }^{1} \mathrm{H} \mathrm{NMR}\left(\mathrm{CDCl}_{3}\right.$, $500 \mathrm{MHz}) \delta 7.51$ (d, $J=7.1,2 \mathrm{H}), 7.36(\mathrm{t}, J=7.4,2 \mathrm{H}), 7.27(\mathrm{t}, J=7.4,1 \mathrm{H}), 1.90(\mathrm{~s}, 3 \mathrm{H}), 1.57$ (s, $2 \mathrm{H}), 1.09$ (s, $18 \mathrm{H}) ;{ }^{13} \mathrm{C} \mathrm{NMR}\left(\mathrm{CDCl}_{3}, 125 \mathrm{MHz}\right) \delta 150.7,136.1,128.0,127.9,127.3,109.8,27.2,20.3,18.3$, 17.7; IR (thin film) 2931, 2857, 1470, 1138, $825 \mathrm{~cm}^{-1}$; HRMS (CI) $\mathrm{m} / \mathrm{z}$ calcd for $\mathrm{C}_{18} \mathrm{H}_{28} \mathrm{OSi}(\mathrm{M})^{+}$288.1909, found 288.1891.

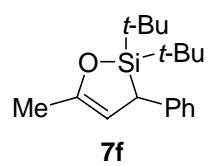

\section{Oxasilacyclopentene (7f).}

To a flask containing $\mathrm{AgOCOCF}_{3}(0.001 \mathrm{~g}, 0.005 \mathrm{mmol})$ was added trans-4-phenyl-3-buten-2-one (0.149 g, $1.02 \mathrm{mmol})$ in $2.0 \mathrm{~mL}$ of $\mathrm{CH}_{2} \mathrm{Cl}_{2}$ followed by cyclohexene silacyclopropane 2 (0.236 g, $\left.1.05 \mathrm{mmol}\right)$ in $2.0 \mathrm{~mL}$ of $\mathrm{CH}_{2} \mathrm{Cl}_{2}$. After $1.5 \mathrm{~h}$, the solution was concentrated in vacuo and chromatographed (1:99 $\mathrm{Et}_{3} \mathrm{~N}$ :pentane) to afford the product as a colorless oil $(0.149 \mathrm{~g}, 52 \%):{ }^{1} \mathrm{H}$ NMR $\left(\mathrm{CDCl}_{3}, 500 \mathrm{MHz}\right) \delta 7.21(\mathrm{~m}, 4 \mathrm{H}), 7.08(\mathrm{t}, J=$ 7.2, 1H), $4.89(\mathrm{~m}, 1 \mathrm{H}), 3.53(\mathrm{~m}, 1 \mathrm{H}), 1.94(\mathrm{dd}, J=1.0,2.4,3 \mathrm{H}), 1.15(\mathrm{~s}, 9 \mathrm{H}), 0.75(\mathrm{~s}, 9 \mathrm{H}) ;{ }^{13} \mathrm{C} \mathrm{NMR}\left(\mathrm{CDCl}_{3}\right.$, $125 \mathrm{MHz}) \delta 157.7,143.3,128.2,127.7,124.7,102.8,34.2,27.7,27.5,22.2,21.2,18.3$; ${ }^{29} \mathrm{Si} \mathrm{NMR}\left(\mathrm{CDCl}_{3}, 99.3\right.$ MHz) $\delta$ 30.7; IR (thin film): 2859, 1652, 1094, 919, $822 \mathrm{~cm}^{-1}$.

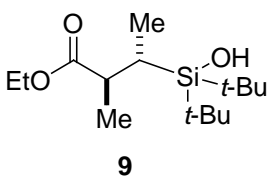

\section{Silanol (9).}

To a solution of $\operatorname{AgOCOCF}_{3}(0.002 \mathrm{~g}, 0.007 \mathrm{mmol})$ in $1.0 \mathrm{~mL}$ of toluene was added ethyl tiglate $(0.061 \mathrm{~g}, 0.47$ mmol) followed by cyclohexene silacyclopropane $2(0.10 \mathrm{~g}, 0.45 \mathrm{mmol})$ in $1.0 \mathrm{~mL}$ of toluene. After $2 \mathrm{~h}$, the mixture was poured into $30 \mathrm{~mL}$ of $\mathrm{NaHCO}_{3}$ (saturated, aq) and the aqueous layer was extracted with $2 \times 30 \mathrm{~mL}$ of $\mathrm{Et}_{2} \mathrm{O}$. The combined organic layers were washed with $30 \mathrm{~mL}$ of brine, dried $\left(\mathrm{MgSO}_{4}\right)$, filtered, and concentrated in vacuo. Column chromatography (95:5 hexanes:EtOAc) afforded the product as a clear oil (0.091 g, 70\%): ${ }^{1} \mathrm{H}$ NMR $\left(\mathrm{CDCl}_{3}, 500 \mathrm{MHz}\right) \delta 4.13$ (q, $\left.J=7.1,2 \mathrm{H}\right), 2.68(\mathrm{qd}, J=7.0,16.6,1 \mathrm{H}), 1.54(\mathrm{qd}, J=$ 7.8, 17.3, 1H), 1.27 (t, $J=7.1,3 \mathrm{H}), 1.21(\mathrm{~d}, J=7.0,3 \mathrm{H}), 1.15(\mathrm{~d}, J=7.8,3 \mathrm{H}), 1.08(\mathrm{~s}, 9 \mathrm{H}), 1.05(\mathrm{~s}, 9 \mathrm{H}) ;{ }^{13} \mathrm{C}$ NMR $\left(\mathrm{CDCl}_{3}, 125 \mathrm{MHz}\right) \delta 179.3,60.6,41.8,28.9,28.3,22.1,21.2,21.1,17.0,14.3,13.2$; IR (thin film) 3507, 2934, 2861, 1732, $829 \mathrm{~cm}^{-1}$; HRMS (CI) $\mathrm{m} / \mathrm{z}$ calcd for $\mathrm{C}_{14} \mathrm{H}_{29} \mathrm{O}_{3} \mathrm{Si}\left(\mathrm{M}-\mathrm{CH}_{3}\right)^{+}$273.1886, found 273.1885.

Anal. Calcd for $\mathrm{C}_{15} \mathrm{H}_{32} \mathrm{O}_{3} \mathrm{Si}$ : C, 62.45; H, 11.18. Found: C, 62.34; H, 11.20. 


\section{Ireland-Claisen Rearrangements and Utility of Products}

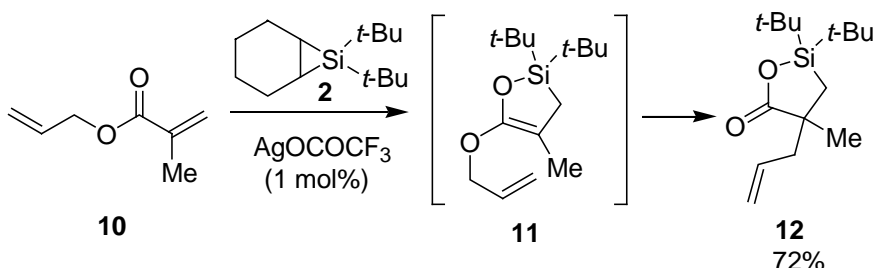

\section{Oxasilacyclopentane (12).}

To an NMR tube containing $\mathrm{AgOCOCF}_{3}(0.0002 \mathrm{~g}, 0.001 \mathrm{mmol})$ was added allyl methacrylate $(0.022 \mathrm{~mL}, 0.16$ mmol) followed by cyclohexene silacyclopropane $2(0.148 \mathrm{~g}, 0.322 \mathrm{mmol})$ in $0.7 \mathrm{~mL}$ of a $0.153 \mathrm{M}$ solution of $\mathrm{PhSi}\left(\mathrm{CH}_{3}\right)_{3}$ in $\mathrm{C}_{6} \mathrm{D}_{6}$. After 20 min, the yield of 11 was found to be $45 \%$ and the yield of 12 was found to be 14\%. The peaks associated with 11 slowly decreased as peaks associated with 12 increased. After 23 h, complete conversion of $\mathbf{1 1}$ to 12 was observed and the solution was filtered through Celite, rinsed with $\mathrm{CH}_{2} \mathrm{Cl}_{2}$, and concentrated in vacuo. Column chromatography (100\% hexanes to 97:3 hexanes:EtOAc) afforded the product as an oil (0.031 g, 72\%): ${ }^{1} \mathrm{H} \mathrm{NMR}\left(\mathrm{CDCl}_{3}, 500 \mathrm{MHz}\right) \delta 5.84(\mathrm{tdd}, J=7.3,10.2,17.3,1 \mathrm{H}), 5.15(\mathrm{~m}$, 2H), 2.47 (dd, $J=7.2,13.8,1 \mathrm{H}), 2.31$ (dd, $J=7.5,13.8,1 \mathrm{H}), 1.33$ (s, 3H), 1.20 (d, $J=16.1,1 \mathrm{H}), 1.09$ (s, $9 \mathrm{H}$ ), 1.08 (s, 9H), 0.81 (d, $J=16.1,1 \mathrm{H}) ;{ }^{13} \mathrm{C} \mathrm{NMR}\left(\mathrm{CDCl}_{3}, 125 \mathrm{MHz}\right) \delta 181.6,133.6,119.1,45.2,45.0,27.33$, 27.30, 27.0, 19.73, 19.71, 14.8; IR (thin film) 2934, 2862, 1746, 1473, $1135 \mathrm{~cm}^{-1}$; HRMS (ES) $\mathrm{m} / \mathrm{z}$ calcd for $\mathrm{C}_{15} \mathrm{H}_{28} \mathrm{O}_{2} \mathrm{Si}(\mathrm{M}+\mathrm{Na})^{+}$291.1756, found 291.1746. Anal. Calcd for $\mathrm{C}_{15} \mathrm{H}_{28} \mathrm{O}_{2} \mathrm{Si}: \mathrm{C}, 67.11 ; \mathrm{H}, 10.51$. Found: C, 67.54; H, 10.94.

\section{Silalactone (15a).}

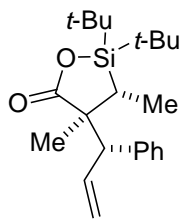

To a flask containing cinnamyl tiglate 13a $(0.213 \mathrm{~g}, 0.986 \mathrm{mmol})$ was added $\operatorname{AgOCOCF}_{3}(0.002 \mathrm{~g}, 0.009$ $\mathrm{mmol})$ in $2.0 \mathrm{~mL}$ of benzene followed by cyclohexene silacyclopropane 2 ( $0.449 \mathrm{~g}, 2.00 \mathrm{mmol})$ in $2.35 \mathrm{~mL}$ of benzene. After $15 \mathrm{~h}$, the mixture was filtered through Celite, rinsed with $\mathrm{CHCl}_{2}$, and concentrated in vacuo. Analysis of the unpurified reaction mixture by gas chromatography revealed a 97:3 ratio of stereoisomers. Column chromatography (100\% hexanes to 95:5 hexanes:EtOAc) and recrystallization from hexanes afforded the product as colorless crystals (0.339 g, 96\%): $\mathrm{mp} 122-125{ }^{\circ} \mathrm{C} ;{ }^{1} \mathrm{H} \mathrm{NMR}\left(\mathrm{CDCl}_{3}, 500 \mathrm{MHz}\right) \delta 7.33(\mathrm{~d}, J=$ 7.2, 2H), 7.25 (dd, $J=7.5,7.9,2 \mathrm{H}), 7.16(\mathrm{t}, J=7.3,1 \mathrm{H}), 6.33(\mathrm{~m}, 1 \mathrm{H}), 5.19(\mathrm{~m}, 2 \mathrm{H}), 4.00(\mathrm{~d}, J=10.8,1 \mathrm{H})$, $2.02(\mathrm{q}, J=7.8,1 \mathrm{H}), 1.34(\mathrm{~s}, 3 \mathrm{H}), 1.24(\mathrm{~d}, J=7.8,3 \mathrm{H}), 1.11(\mathrm{~s}, 9 \mathrm{H}), 0.60(\mathrm{~s}, 9 \mathrm{H}) ;{ }^{13} \mathrm{C} \mathrm{NMR}\left(\mathrm{CDCl}_{3}, 125 \mathrm{MHz}\right)$ $\delta$ 180.8, 141.1, 136.2, 129.8, 128.5, 127.0, 118.6, 58.6, 52.4, 28.4, 27.2, 22.6, 21.1, 20.3, 18.3, 11.7; IR (thin film) 2938, 2861, 1736, 1474, $914 \mathrm{~cm}^{-1}$; HRMS (ES) $\mathrm{m} / \mathrm{z}$ calcd for $\mathrm{C}_{22} \mathrm{H}_{34} \mathrm{O}_{2} \mathrm{Si}(\mathrm{M}+\mathrm{H})^{+} 359.2406$, found 359.2392. Anal. Calcd for $\mathrm{C}_{22} \mathrm{H}_{34} \mathrm{O}_{2} \mathrm{Si}$ : C, 73.69; H, 9.56. Found: C, 73.41; H, 9.62.

Diol 16 was constructed in three steps from ester 13b (Scheme S-1). Silylene transfer to the ester provided silalactone $\mathbf{1 5 b}$ and reduction of $\mathbf{1 5 b}$ afforded intermediate A. Oxidation of A afforded diol 16. Experimentals for these transformations follow: 


\section{Scheme S-1}

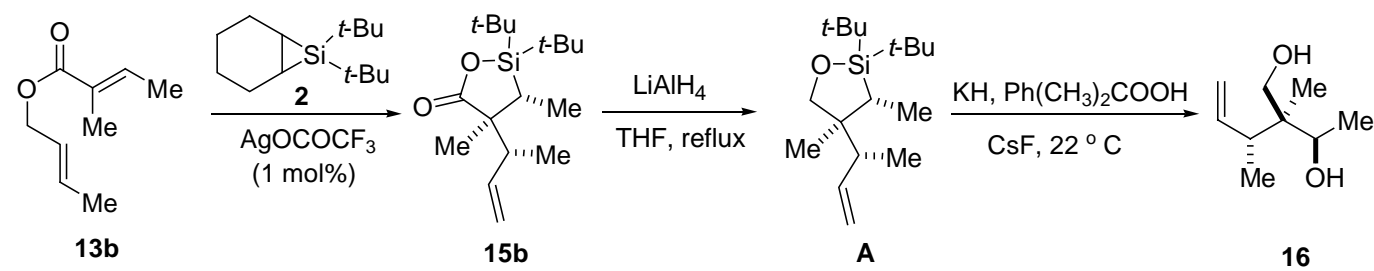

\section{Crotyl Tiglate (13b).}

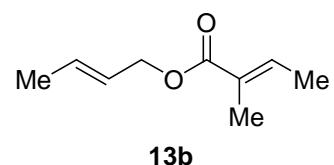

To a solution of tiglic acid (3.90 g, $30.8 \mathrm{mmol})$ in $\mathrm{CH}_{2} \mathrm{Cl}_{2}(66.7 \mathrm{~mL})$ was added 4-(dimethylamino)pyridine (0.122 g, $1.00 \mathrm{mmol})$ and crotyl alcohol (1.69 mL, $20.0 \mathrm{mmol})$, followed by $N, N$ '-dicyclohexylcarbodiimide $(6.19 \mathrm{~g}, 30.0 \mathrm{mmol})$. After $14 \mathrm{~h}$, the precipitated urea was filtered off and the filtrate was rinsed with $\mathrm{CH}_{2} \mathrm{Cl}_{2}$ and concentrated in vacuo. Column chromatography (100\% pentane to 97:3 pentane:Et $2 \mathrm{O}$ ) afforded the product as a colorless oil (2.19 g, 71\%): ${ }^{1} \mathrm{H} \mathrm{NMR}\left(\mathrm{CDCl}_{3}, 500 \mathrm{MHz}\right) \delta 6.86(\mathrm{qd}, J=1.4,7.1,1 \mathrm{H}), 5.79(\mathrm{~m}, 1 \mathrm{H}), 5.62$ (m, $1 \mathrm{H}), 4.56$ (d, $J=6.4,2 \mathrm{H}), 1.84$ (s, 3H), 1.78 (dd, $J=1.0,7.1,3 \mathrm{H}), 1.72(\mathrm{dd}, J=1.1,6.5,3 \mathrm{H})$; ${ }^{13} \mathrm{C} \mathrm{NMR}$ $\left(\mathrm{CDCl}_{3}, 125 \mathrm{MHz}\right) \delta 167.9,137.1,130.7,128.7,125.5,65.1,17.8,14.3,12.0$; IR (thin film) 2921, 1708, 1653, $1251 \mathrm{~cm}^{-1}$.

\section{Silalactone (15b).}

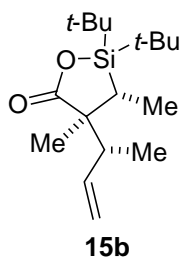

To a flask containing $\mathrm{AgOCOCF}_{3}(0.002 \mathrm{~g}, 0.010 \mathrm{mmol})$ was added crotyl tiglate $\mathbf{1 3 b}(0.155 \mathrm{~g}, 1.00 \mathrm{mmol})$ in $2.35 \mathrm{~mL}$ of toluene followed by cyclohexene silacyclopropane $2(0.449 \mathrm{~g}, 2.00 \mathrm{mmol})$ in $2.0 \mathrm{~mL}$ of toluene. After $23 \mathrm{~h}$, the solution was filtered over silica gel, which was rinsed with $\mathrm{CH}_{2} \mathrm{Cl}_{2}$, and the filtrate was concentrated in vacuo. Analysis of the unpurified reaction mixture by gas chromatography revealed the product to be a single stereoisomer. Column chromatography (100\% hexanes to 97:3 hexanes: $\mathrm{Et}_{2} \mathrm{O}$ ) afforded 15b as colorless crystals $(0.283 \mathrm{~g}, 95 \%)$ : $\mathrm{mp} 74-76{ }^{\circ} \mathrm{C} ;{ }^{1} \mathrm{H} \mathrm{NMR}\left(\mathrm{CDCl}_{3}, 400 \mathrm{MHz}\right) \delta 5.76$ (ddd, $J=9.0,10.6,17.0$, 1H), $5.09(\mathrm{~m}, 2 \mathrm{H}), 2.62(\mathrm{~m}, 1 \mathrm{H}), 1.82$ (q, $J=7.8,1 \mathrm{H}), 1.29(\mathrm{~s}, 3 \mathrm{H}), 1.15(\mathrm{~m}, 12 \mathrm{H}), 1.11(\mathrm{~s}, 9 \mathrm{H}), 1.05$ (d, $J=$ 6.8, 3H); ${ }^{13} \mathrm{C} \mathrm{NMR}\left(\mathrm{CDCl}_{3}, 125 \mathrm{MHz}\right) \delta$ 181.3, 139.4, 116.6, 51.1, 48.2, 28.5, 28.3, 21.7, 21.2, 18.1, 17.2, 11.8; IR (thin film) 2939, 2862, 1745, 913, $822 \mathrm{~cm}^{-1}$; HRMS (ES) $\mathrm{m} / \mathrm{z}$ calcd for $\mathrm{C}_{17} \mathrm{H}_{32} \mathrm{O}_{2} \mathrm{Si}(\mathrm{M}+\mathrm{H})^{+} 297.2250$, found 297.2254. Anal. Calcd for $\mathrm{C}_{17} \mathrm{H}_{32} \mathrm{O}_{2} \mathrm{Si}$ : C, 68.86; H, 10.88. Found: C, 68.84; H, 11.01.

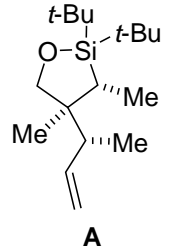

\section{Oxasilacyclopentane (A).}

To a cooled $\left(0^{\circ} \mathrm{C}\right)$ solution of silalactone $15 \mathrm{~b}(0.134 \mathrm{~g}, 0.453 \mathrm{mmol})$ in $2.5 \mathrm{~mL}$ of THF was added $\mathrm{LiAlH}_{4}$ (0.061 g, $1.6 \mathrm{mmol})$. The cold bath was removed, a reflux condenser was affixed to the flask, and the solution 
was heated to $90{ }^{\circ} \mathrm{C}$. After $22 \mathrm{~h}, 0.060 \mathrm{~mL}$ of water was added, followed by $0.060 \mathrm{~mL}$ of $\mathrm{NaOH}(15 \%$ aq solution) and then an additional $0.180 \mathrm{~mL}$ of water. $\mathrm{NaSO}_{4}$ was added to the solution, and the solution was filtered. The filter cake was rinsed with $\mathrm{Et}_{2} \mathrm{O}$ and the filtrate was concentrated in vacuo. Column chromatography (97:3 hexanes:EtOAc) afforded product $\mathbf{A}$ as a colorless oil $(0.12 \mathrm{~g}, 94 \%):{ }^{1} \mathrm{H} \mathrm{NMR}\left(\mathrm{CDCl}_{3}\right.$, $500 \mathrm{MHz}) \delta 5.75(\mathrm{~m}, 1 \mathrm{H}), 4.99(\mathrm{~m}, 2 \mathrm{H}), 3.70(\mathrm{~d}, J=9.8,1 \mathrm{H}), 3.61(\mathrm{~d}, J=9.8,1 \mathrm{H}), 2.19(\mathrm{~m}, 1 \mathrm{H}), 1.52(\mathrm{q}, J=$ 7.8, 1H), 1.12 (d, $J=7.8,1 \mathrm{H}), 1.10(\mathrm{~s}, 9 \mathrm{H}), 1.034$ (d, $J=7.2,3 \mathrm{H}), 1.027(\mathrm{~s}, 9 \mathrm{H}) ;{ }^{13} \mathrm{C} \mathrm{NMR}\left(\mathrm{CDCl}_{3}, 125 \mathrm{MHz}\right)$ $\delta$ 141.4, 114.6, 76.8, 47.5, 45.0, 28.9, 28.4, 24.5, 22.4, 21.1, 18.8, 15.9, 10.8; IR (thin film) 2934, 2859, 1472, 1031, $822 \mathrm{~cm}^{-1}$; HRMS (ES) $\mathrm{m} / \mathrm{z}$ calcd for $\mathrm{C}_{17} \mathrm{H}_{34} \mathrm{OSi}(\mathrm{M}+\mathrm{H})^{+}$283.2457, found 283.2458. Anal. Calcd for $\mathrm{C}_{17} \mathrm{H}_{34} \mathrm{O}_{2} \mathrm{Si}$ : C, 72.27; H, 12.13. Found: C, 72.18; H, 12.31 .

\section{Diol (16).}

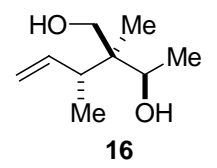

To a cooled $\left(0{ }^{\circ} \mathrm{C}\right)$ solution of $\mathrm{KH}(0.048 \mathrm{~g}, 1.2 \mathrm{mmol})$ in $0.67 \mathrm{~mL}$ of 1-methyl-2-pyrrolidinone (NMP) was added cumene hydroperoxide $(0.100 \mathrm{~mL}, 88.0 \%$ solution, $0.600 \mathrm{mmol})$. After $5 \mathrm{~min}$, the cold bath was removed and substrate $\mathbf{A}(0.056 \mathrm{~g}, 0.20 \mathrm{mmol})$ was added in $0.67 \mathrm{~mL}$ of NMP and rinsed with $0.67 \mathrm{~mL}$ of THF. After $10 \mathrm{~min}, \mathrm{CsF}(0.181 \mathrm{~g}, 1.20 \mathrm{mmol})$ was added. The solution was stirred at $22{ }^{\circ} \mathrm{C}$ for $6.5 \mathrm{~h}$ and then diluted with $5 \mathrm{~mL}$ of $\mathrm{Na}_{2} \mathrm{~S}_{2} \mathrm{O}_{3}$ (saturated, aq). This mixture was poured into $10 \mathrm{~mL}$ of water and extracted with $3 \times 10$ $\mathrm{mL}$ of $\mathrm{CH}_{2} \mathrm{Cl}_{2}$. The combined organic layers were washed with $4 \times 5 \mathrm{~mL}$ of water, $10 \mathrm{~mL}$ of brine, dried $\left(\mathrm{Na}_{2} \mathrm{SO}_{4}\right)$, filtered, and concentrated in vacuo. Column chromatography (80:20 to 70:30 pentane:Et $\left.{ }_{2} \mathrm{O}\right)$ afforded 16 as a colorless oil $(0.029 \mathrm{~g}, 93 \%):{ }^{1} \mathrm{H} \mathrm{NMR}\left(\mathrm{CDCl}_{3}, 500 \mathrm{MHz}\right) \delta 5.87$ (ddd, $\left.J=9.0,10.2,17.1,1 \mathrm{H}\right), 5.10$ (ddd, $J=0.9,2.0,17.1,1 \mathrm{H}), 5.05$ (dd, $J=2.0,10.2,1 \mathrm{H}), 3.93$ (q, $J=6.2,1 \mathrm{H}), 3.71(\mathrm{~d}, J=11.2,1 \mathrm{H}), 3.60(\mathrm{~d}, J$ $=11.2,1 \mathrm{H}), 2.80(\mathrm{p}, J=6.9,1 \mathrm{H}), 2.74($ br s, $1 \mathrm{H}), 2.59$ (br s, $1 \mathrm{H}), 1.26(\mathrm{~d}, J=6.4,3 \mathrm{H}), 1.03(\mathrm{~d}, J=6.9,3 \mathrm{H})$, 0.63 (s, 3H); ${ }^{13} \mathrm{C} \mathrm{NMR}\left(\mathrm{CDCl}_{3}, 125 \mathrm{MHz}\right) \delta$ 141.2, 115.2, 72.7, 66.6, 42.8, 39.2, 18.3, 14.26, 14.24; IR (thin film) 3361, 2973, 2926, 1038, $915 \mathrm{~cm}^{-1}$; HRMS (ES) $\mathrm{m} / \mathrm{z}$ calcd for $\mathrm{C}_{9} \mathrm{H}_{18} \mathrm{O}_{2}(\mathrm{M}+\mathrm{Na})^{+} 181.1205$, found 181.1200.

\section{Aldol Reactions of Intermediate Oxasilacyclopentenes}

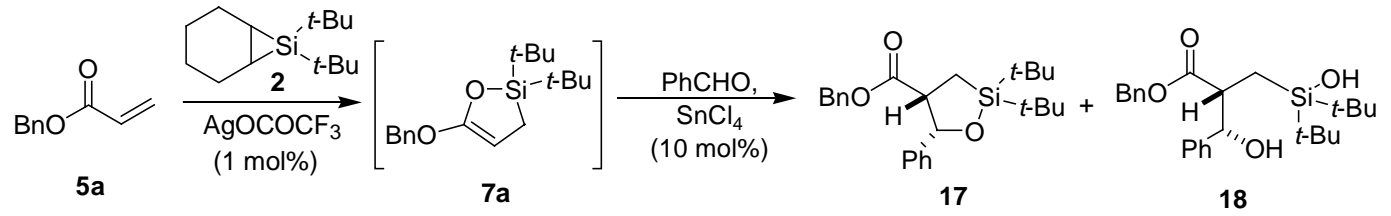

Oxasilacyclopentane (17) and Silanol (18).

To a stirred solution of $\operatorname{AgOCOCF}_{3}(0.002 \mathrm{~g}, 0.01 \mathrm{mmol})$ in $5.0 \mathrm{~mL}$ of $\mathrm{CH}_{2} \mathrm{Cl}_{2}$ was added benzyl acrylate $(0.236 \mathrm{~g}, 1.46 \mathrm{mmol})$ and a solution of cyclohexene silacyclopropane $2(0.336 \mathrm{~g}, 1.50 \mathrm{mmol})$ in $1.0 \mathrm{~mL}$ of $\mathrm{CH}_{2} \mathrm{Cl}_{2}$. After $1.5 \mathrm{~h}$, the solution was cooled to $-78^{\circ} \mathrm{C}$ and benzaldehyde $(0.153 \mathrm{~mL}, 1.500 \mathrm{mmol})$ was added, followed by $\mathrm{SnCl}_{4}\left(0.150 \mathrm{~mL}\right.$ of a $1.0 \mathrm{M}$ solution in $\left.\mathrm{CH}_{2} \mathrm{Cl}_{2}\right)$. The solution was stirred for $3 \mathrm{~h}$ at $-78{ }^{\circ} \mathrm{C}$, then it was diluted with $30 \mathrm{~mL}$ of $\mathrm{NaHCO}_{3}$ (saturated, aq) and the aqueous layer was extracted with $3 \times 30 \mathrm{~mL}$ of $\mathrm{CH}_{2} \mathrm{Cl}_{2}$. The combined organic layers were washed with $20 \mathrm{~mL}$ of brine, dried $\left(\mathrm{Na}_{2} \mathrm{SO}_{4}\right)$, filtered, and concentrated in vacuo. Analysis of the unpurified reaction mixture by gas chromatography revealed a 90:10 ratio of diastereomers. Column chromatography (10:90 EtOAc:hexanes) afforded oxasilacyclopentane 17 (0.291 g, 48\%) as a mixture of diastereomers (89:11) and silanol 18 (0.626 g, 20\%) as a single diastereomer. 


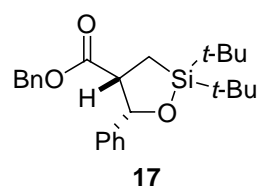

Oxasilacyclopentane syn-17. ${ }^{1} \mathrm{H}$ NMR $\left(\mathrm{CDCl}_{3}, 500 \mathrm{MHz}\right) \delta 7.32(\mathrm{~m}, 10 \mathrm{H}), 5.48(\mathrm{~d}, J=8.7,1 \mathrm{H}), 4.72(\mathrm{~d}, J=$ $12.1,1 \mathrm{H}$ ), 4.29 (d, $J=12.1,1 \mathrm{H}), 3.63$ (ddd, $J=7.1,8.7,10.1,1 \mathrm{H}), 1.56$ (dd, $J=15.0,7.0,1 \mathrm{H}), 1.25$ (dd, $J=$

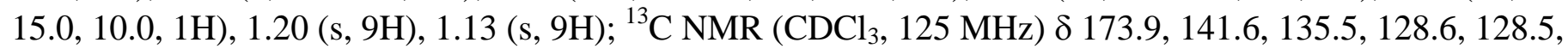
128.2, 128.1, 127.6, 126.9, 81.7, 66.5, 48.5, 28.5, 28.0, 21.6, 20.2, 8.8; IR (thin film) 2932, 2858, 1736, 1169, 1023, $824 \mathrm{~cm}^{-1}$; HRMS (CI) $\mathrm{m} / \mathrm{z}$ calcd for $\mathrm{C}_{25} \mathrm{H}_{33} \mathrm{O}_{3} \mathrm{Si}(\mathrm{M}-\mathrm{H})^{+}$409.2199, found 409.2208. Anal. Calcd for $\mathrm{C}_{25} \mathrm{H}_{34} \mathrm{O}_{3} \mathrm{Si}$ : C, 73.13; H, 8.35. Found: C, 72.91; H, 8.49.

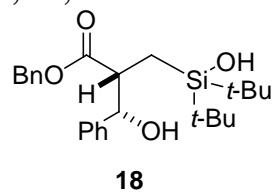

Silanol 18. ${ }^{1} \mathrm{H}$ NMR $\left(\mathrm{CDCl}_{3}, 500 \mathrm{MHz}\right) \delta 7.34$ (m, 10H), 5.14 (s, 2H), 4.84 (d, $\left.J=7.3,1 \mathrm{H}\right), 3.04$ (ddd, $J=3.6$, 7.4, $10.91 \mathrm{H}$ ), 2.81 (br s, 1H), 2.23 (br s, 1H), 0.99 (dd, $J=10.9,15.3,1 \mathrm{H}), 0.91$ (s, 9H), 0.82 (s, $9 \mathrm{H}), 0.71$ (dd, $J=3.6,15.3,1 \mathrm{H}) ;{ }^{13} \mathrm{C} \mathrm{NMR}\left(\mathrm{CDCl}_{3}, 125 \mathrm{MHz}\right) \delta$ 176.2. 141.8, 135.5, 128.8, 128.61, 128.58, 128.5, 128.2, 126.8, 67.0, 49.3, 27.5, 27.4, 20.7, 20.5, 9.7; IR (thin film) 3401, 2861, 1708, 1461, 1161, $820 \mathrm{~cm}^{-1}$; HRMS (CI) $\mathrm{m} / \mathrm{z}$ calcd for $\mathrm{C}_{21} \mathrm{H}_{25} \mathrm{O}_{3} \mathrm{Si}\left(\mathrm{M}-\mathrm{H}_{2} \mathrm{O}-t-\mathrm{Bu}\right)^{+}$353.1573, found 353.1581. Anal. Calcd for $\mathrm{C}_{25} \mathrm{H}_{36} \mathrm{O}_{4} \mathrm{Si}: \mathrm{C}$, 70.05; H, 8.47. Found: C, 70.37; H, 8.65.

\section{Stereochemical Assignment of Aldol Products}

\section{nOe experiments:}

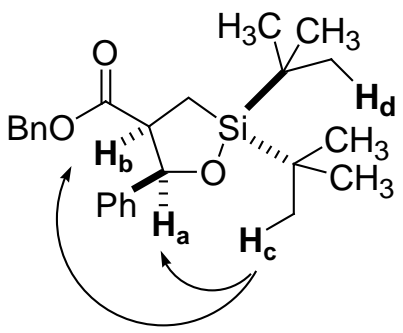

Oxasilacyclopentene (17):

17

$\mathbf{H}_{\mathbf{a}}$ irradiated: $11.7 \%$ nOe observed to $\mathbf{H}_{\mathbf{b}}, 5.73 \%$ nOe observed to $\mathbf{H}_{c}$, no nOe to $\mathbf{H}_{\mathbf{d}}$ $\mathbf{H}_{\mathbf{b}}$ irradiated: $12.2 \%$ nOe observed to $\mathbf{H}_{\mathbf{a}}, 5.92 \%$ nOe observed to $\mathbf{H}_{\mathbf{c}}$, no nOe to $\mathbf{H}_{\mathbf{d}}$ $\mathbf{H}_{\mathbf{c}}$ irradiated: $2.9 \%$ nOe observed to $\mathbf{H}_{\mathbf{a}}, 1.8 \%$ nOe observed to $\mathbf{H}_{\mathbf{b}}$

The stereochemistry of the open aldol product (18) is the same as the major diastereomer of the closed aldol product (17). Analysis by gas chromatography (GC) showed the same retention times for $\mathbf{1 8}$ and syn-17. High temperatures of the GC most likely caused silanol $\mathbf{1 8}$ to cyclize to the closed product (17).

To further prove that $\mathbf{1 8}$ and the major isomer of $\mathbf{1 7}$ contain the same stereochemistry, the following experiments were undertaken. Under slightly modified aldol reaction conditions, a 90:10 ratio of diastereomers was achieved. Treatment of a similar reaction mixture with $\mathrm{BF}_{3} \cdot \mathrm{OEt}_{2}$ provided the open aldol product with fluorine incorporation as an 89:11 ratio of diastereomers. Treatment of the isolated compounds $\mathbf{1 7}$ and $\mathbf{1 8}$ with 
$\mathrm{BF}_{3} \cdot \mathrm{OEt}_{2}$ afforded the same major product (19). Compounds syn-17, 18, and 19 all have the same retention times by GC.
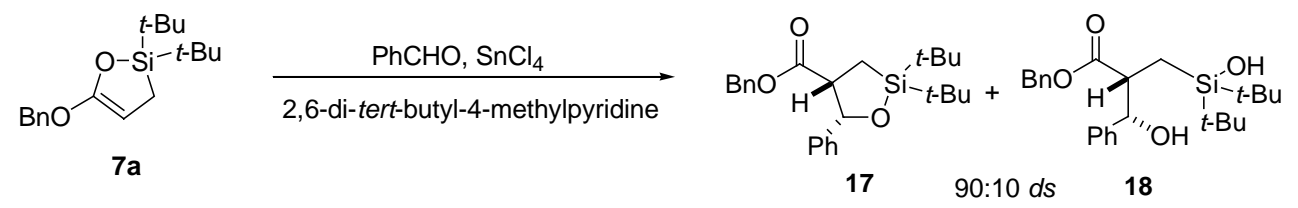

Oxasilacyclopentane (17) and Silanol (18).

To a solution of oxasilacyclopentene $7 \mathbf{a}(0.0614 \mathrm{~g}, 0.202 \mathrm{mmol})$ in $1.0 \mathrm{~mL}$ of $\mathrm{CH}_{2} \mathrm{Cl}_{2}$ was added benzaldehyde (0.022 mL, $0.21 \mathrm{mmol})$ and 2,6-di-tert-butyl-4-methylpyridine (0.044 g, $0.21 \mathrm{mmol})$. The solution was cooled to $-78{ }^{\circ} \mathrm{C}$ and $\mathrm{SnCl}_{4}\left(0.212 \mathrm{~mL}\right.$ of a $1.0 \mathrm{M}$ solution in $\left.\mathrm{CH}_{2} \mathrm{Cl}_{2}\right)$ was added dropwise. After $8 \mathrm{~h}$, the mixture was

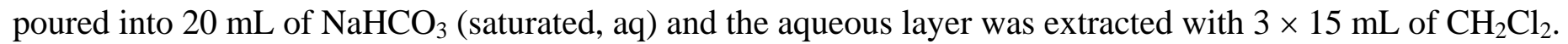
The combined organic layers were washed with $20 \mathrm{~mL}$ of brine, dried $\left(\mathrm{Na}_{2} \mathrm{SO}_{4}\right)$, filtered, and concentrated in vacuo. Analysis of the unpurified reaction mixture by gas chromatography revealed a 90:10 ratio of diastereomers (syn-17 and syn-18 to anti-17). Column chromatography (5:95 to 15:85 EtOAc:hexanes) afforded oxasilacyclopentane 17 (0.0313 g, 38\%) as a mixture of diastereomers and silanol 18 (0.0154 g, 18\%) as a single diastereomer.
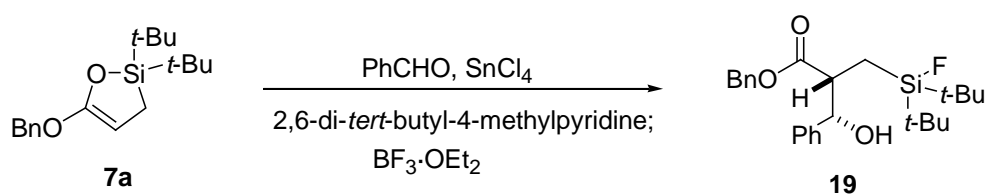

\section{Fluorosilane (19).}

To a solution of oxasilacyclopentene $7 \mathrm{a}(0.0564 \mathrm{~g}, 0.185 \mathrm{mmol})$ in $0.5 \mathrm{~mL}$ of $\mathrm{CH}_{2} \mathrm{Cl}_{2}$ was added benzaldehyde (0.020 mL, $0.195 \mathrm{mmol}$ ) and 2,6-di-tert-butyl-4-methylpyridine (0.0400 g, $0.195 \mathrm{mmol})$. The solution was cooled to $-78{ }^{\circ} \mathrm{C}$ and $\mathrm{SnCl}_{4}\left(0.195 \mathrm{~mL}\right.$ of a $1.0 \mathrm{M}$ solution in $\left.\mathrm{CH}_{2} \mathrm{Cl}_{2}\right)$ was added dropwise. After $2 \mathrm{~h}, \mathrm{BF}_{3} \cdot \mathrm{OEt}_{2}$ was added to the solution. After an additional $2 \mathrm{~h}$ at $-78{ }^{\circ} \mathrm{C}$, the mixture was poured into $20 \mathrm{~mL}$ of $\mathrm{NaHCO}_{3}$ (saturated, aq) and the aqueous layer was extracted with $3 \times 10 \mathrm{~mL}$ of $\mathrm{CH}_{2} \mathrm{Cl}_{2}$. The combined organic layers were washed with $2 \times 20 \mathrm{~mL}$ of $\mathrm{H}_{2} \mathrm{O}$, washed with $20 \mathrm{~mL}$ of brine, dried $\left(\mathrm{Na}_{2} \mathrm{SO}_{4}\right)$, filtered, and concentrated in vacuo. Analysis of the unpurified reaction mixture by gas chromatography revealed an 89:11 ratio of diastereomers (syn-19 to anti-19). Column chromatography (5:95 to 15:85 EtOAc:hexanes) afforded the product $(0.0286 \mathrm{~g}, 36 \%):{ }^{1} \mathrm{H} \mathrm{NMR}\left(\mathrm{CDCl}_{3}, 500 \mathrm{MHz}\right) \delta 7.27(\mathrm{~m}, 10 \mathrm{H}), 5.10(\mathrm{~d}, J=12.3,1 \mathrm{H}), 5.08(\mathrm{~d}, J=12.4$, 1H), 4.75 (t, $J=6.5,1 \mathrm{H}$ ), 3.05 (ddd, $J=5.0,6.5,9.7,1 \mathrm{H}$ ), 2.91 (d, $J=6.6,1 \mathrm{H}$ ), 1.16 (ddd, $J=3.6,9.7,15.2$, 1H), 0.97 (d, $J=1.0,9 H), 0.91$ (d, $J=1.0,9 H), 0.87(\mathrm{~m}, 1 \mathrm{H}) ;{ }^{13} \mathrm{C}$ NMR $\left(\mathrm{CDCl}_{3}, 125 \mathrm{MHz}\right) \delta 175.5,142.1$, 135.8, 128.6, 128.5, 128.3, 128.2, 128.1, 126.5, 77.4, 66.7, 48.1, 27.1, 27.0, $20.6\left(\mathrm{~d},{ }^{2} J_{\mathrm{CF}}=12.5\right), 20.4\left(\mathrm{~d},{ }^{2} J_{\mathrm{CF}}=\right.$ 12.5), 9.7 (d, ${ }^{2} J_{\mathrm{CF}}=12.5$ ); IR (thin film) 3366, 2934, 2343, 1731, 1167, $825 \mathrm{~cm}^{-1}$; HRMS (CI) $\mathrm{m} / \mathrm{z}$ calcd for $\mathrm{C}_{25} \mathrm{H}_{35} \mathrm{FO}_{3} \mathrm{Si}(\mathrm{M}-\mathrm{HF}-t-\mathrm{Bu})^{+}$353.1573, found 353.1578.

\section{References}

(1) Boudjouk, P.; Samaraweera, U.; Sooriyakumaran, R.; Chrusciel, J.; Anderson, K. R. Angew. Chem. Int. Ed. Engl. 1988, 27, 1355-1356.

(2) Driver, T. G.; Franz, A. K.; Woerpel, K. A. J. Am. Chem. Soc. 2002, 124, 6524-6525.

(3) This compound has been previously made by other methods: Zhu, Z.; Rider, J.; Yang, C. Y.; Gilmartin, M. E.; Wnek, G. E. Macromolecules 1992, 25, 7330-7333.

(4) DeShong, P.; Dicken, C. M.; Staib, R. R.; Weinreb, S. M. J. Org. Chem. 1982, 47, 4397-4403. 


\section{X-ray Crystallographic Data}

\section{A. Silalactone 15a}

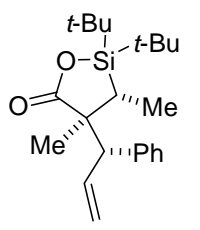

$15 a$

X-ray Data Collection, Structure Solution and Refinement for 15a.

A colorless crystal of approximate dimensions $0.22 \times 0.37 \times 0.44 \mathrm{~mm}$ was mounted on a glass fiber and transferred to a Bruker CCD platform diffractometer. The SMART ${ }^{1}$ program package was used to determine the unit-cell parameters and for data collection (25 sec/frame scan time for a sphere of diffraction data). The raw frame data was processed using $\mathrm{SAINT}^{2}$ and $\mathrm{SADABS}^{3}$ to yield the reflection data file. Subsequent calculations were carried out using the SHELXTL ${ }^{4}$ program. The diffraction symmetry was $2 / m$ and the systematic absences were consistent with the centrosymmetric monoclinic space group $P 2_{1} / n$ which was later determined to be correct.

The structure was solved by direct methods and refined on $\mathrm{F}^{2}$ by full-matrix least-squares techniques. The analytical scattering factors ${ }^{5}$ for neutral atoms were used throughout the analysis. Hydrogen atoms were located from a difference-Fourier map and refined ( $\mathrm{x}, \mathrm{y}, \mathrm{z}$ and $\mathrm{U}_{\mathrm{iso}}$ ). At convergence, wR2 $=0.0938$ and Goof $=1.034$ for 362 variables refined against 5028 unique data. As a comparison for refinement on $\mathrm{F}, \mathrm{R} 1=0.0327$ for those 4327 data with I > 2.0 $(\mathrm{I})$.

References.

1. SMART Software Users Guide, Version 5.1, Bruker Analytical X-Ray Systems, Inc.; Madison, WI 1999.

2. SAINT Software Users Guide, Version 6.0, Bruker Analytical X-Ray Systems, Inc.; Madison, WI 1999.

3. Sheldrick, G. M. SADABS, Version 2.05, Bruker Analytical X-Ray Systems, Inc.; Madison, WI 2001.

4. Sheldrick, G. M. SHELXTL Version 6.12, Bruker Analytical X-Ray Systems, Inc.; Madison, WI 2001.

5. International Tables for X-Ray Crystallography 1992, Vol. C., Dordrecht: Kluwer Academic Publishers. 


\section{Definitions:}

$\mathrm{wR} 2=\left[\Sigma\left[\mathrm{w}\left(\mathrm{F}_{\mathrm{o}}{ }^{2}-\mathrm{F}_{\mathrm{c}}{ }^{2}\right)^{2}\right] / \Sigma\left[\mathrm{w}\left(\mathrm{F}_{\mathrm{o}}{ }^{2}\right)^{2}\right]\right]^{1 / 2}$

$\mathrm{R} 1=\Sigma|| \mathrm{F}_{\mathrm{o}}|-| \mathrm{F}_{\mathrm{c}}|| / \Sigma\left|\mathrm{F}_{\mathrm{o}}\right|$

Goof $=\mathrm{S}=\left[\Sigma\left[\mathrm{w}\left(\mathrm{F}_{\mathrm{o}}^{2}-\mathrm{F}_{\mathrm{c}}^{2}\right)^{2}\right] /(\mathrm{n}-\mathrm{p})\right]^{1 / 2}$ where $\mathrm{n}$ is the number of reflections and $\mathrm{p}$ is the total number of parameters refined.

The thermal ellipsoid plot is shown at the $50 \%$ probability level.
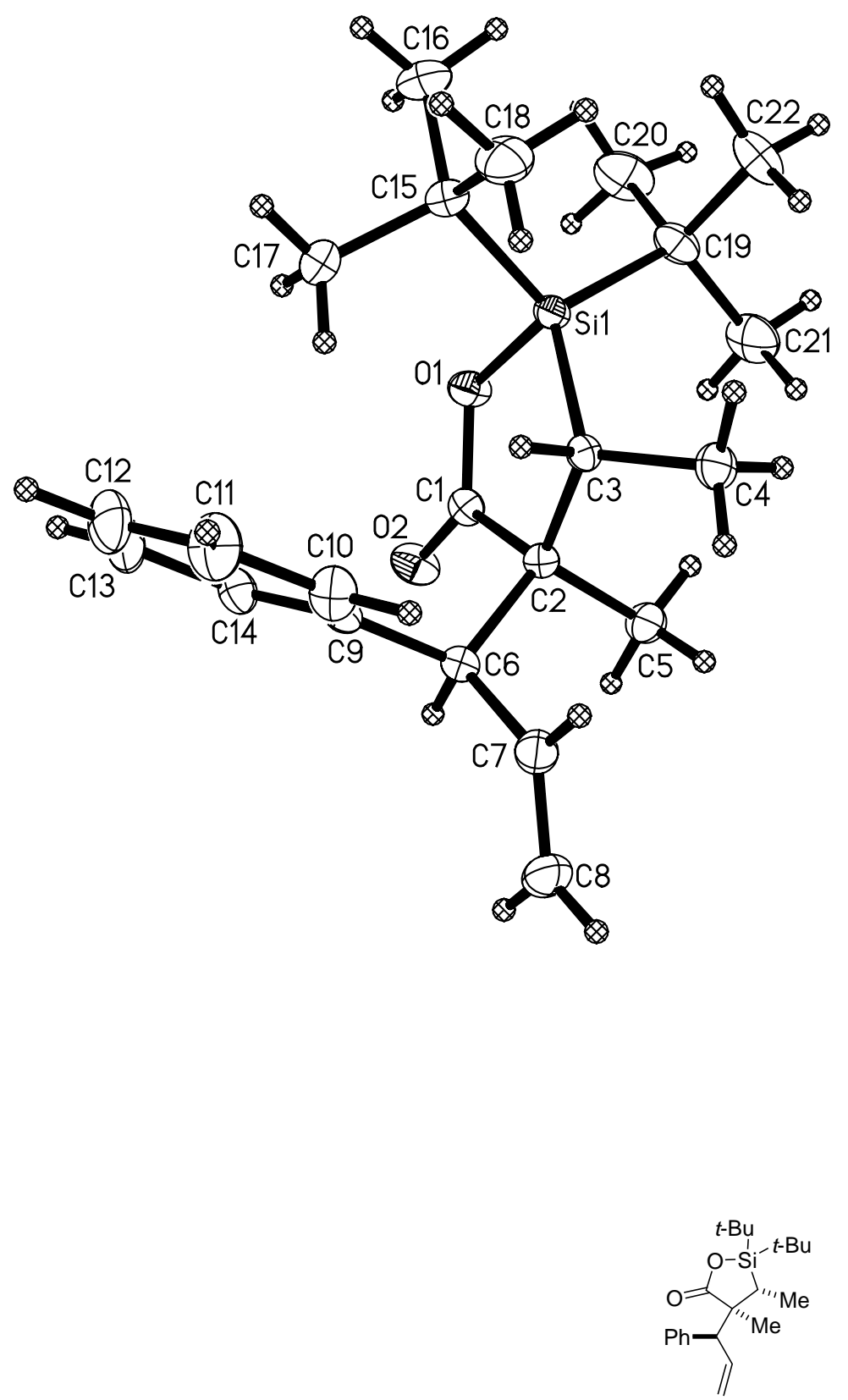
Table 1. Crystal data and structure refinement for $\mathbf{1 5 a}$.

Identification code

Empirical formula

Formula weight

Temperature

Wavelength

Crystal system

Space group

Unit cell dimensions

Volume

$\mathrm{Z}$

Density (calculated)

Absorption coefficient

$\mathrm{F}(000)$

Crystal size

Theta range for data collection

Index ranges

Reflections collected

Independent reflections

Completeness to theta $=28.28^{\circ}$

Absorption correction

Max. and min. transmission

Refinement method

Data / restraints / parameters

Goodness-of-fit on $\mathrm{F}^{2}$

Final R indices [I $>2$ sigma(I); 4327 data]

$\mathrm{R}$ indices (all data)

Largest diff. peak and hole kaw60 (Stacie Calad)

$\mathrm{C}_{22} \mathrm{H}_{34} \mathrm{O}_{2} \mathrm{Si}$

358.58

163(2) K

$0.71073 \AA$

Monoclinic

$P 2{ }_{1} / n$

$\mathrm{a}=10.6806(13) \AA \quad \alpha=90^{\circ}$.

$\mathrm{b}=13.2710(16) \AA$

$\beta=90.257(2)^{\circ}$.

$\mathrm{c}=14.7945(18) \AA$

$\gamma=90^{\circ}$.
2097.0(4) $\AA^{3}$

4

$1.136 \mathrm{Mg} / \mathrm{m}^{3}$

$0.124 \mathrm{~mm}^{-1}$

784

$0.44 \times 0.37 \times 0.22 \mathrm{~mm}^{3}$

2.06 to $28.28^{\circ}$.

$-14 \leq h \leq 14,-17 \leq k \leq 17,-19 \leq l \leq 19$

21777

$5028[\mathrm{R}(\mathrm{int})=0.0224]$

$96.6 \%$

Semi-empirical from equivalents

0.9733 and 0.9475

Full-matrix least-squares on $\mathrm{F}^{2}$

5028 / 0 / 362

1.034

$\mathrm{R} 1=0.0327, \mathrm{wR} 2=0.0875$

$\mathrm{R} 1=0.0400, \mathrm{wR} 2=0.0938$

0.376 and -0.218 e. $\AA^{-3}$ 
Table 2. Atomic coordinates ( x 104) and equivalent isotropic displacement parameters $\left(\AA^{2} \times 10^{3}\right)$ for 15a. $U(e q)$ is defined as one third of the trace of the orthogonalized $U^{i j}$ tensor.

\begin{tabular}{|c|c|c|c|c|}
\hline & $\mathrm{x}$ & $\mathrm{y}$ & $\mathrm{z}$ & $\mathrm{U}(\mathrm{eq})$ \\
\hline $\mathrm{Si}(1)$ & $3362(1)$ & 2956(1) & $1262(1)$ & $17(1)$ \\
\hline $\mathrm{O}(1)$ & $2805(1)$ & 2248(1) & 2133(1) & $22(1)$ \\
\hline $\mathrm{O}(2)$ & 1323(1) & 2185(1) & 3182(1) & $26(1)$ \\
\hline$C(1)$ & 1781(1) & 2617(1) & $2550(1)$ & $17(1)$ \\
\hline$C(2)$ & $1309(1)$ & 3640(1) & 2179(1) & $15(1)$ \\
\hline$C(3)$ & 2004(1) & 3872(1) & $1278(1)$ & $15(1)$ \\
\hline$C(4)$ & 2272(1) & 4986(1) & $1075(1)$ & $25(1)$ \\
\hline$C(5)$ & $1605(1)$ & 4408(1) & 2932(1) & $22(1)$ \\
\hline$C(6)$ & $-158(1)$ & 3562(1) & 2087(1) & 17(1) \\
\hline$C(7)$ & $-760(1)$ & $4580(1)$ & $1946(1)$ & $24(1)$ \\
\hline $\mathrm{C}(8)$ & $-1600(1)$ & 4970(1) & 2496(1) & $32(1)$ \\
\hline$C(9)$ & $-595(1)$ & 2808(1) & $1375(1)$ & 18(1) \\
\hline$C(10)$ & $-932(1)$ & 3101(1) & $502(1)$ & $25(1)$ \\
\hline $\mathrm{C}(11)$ & $-1355(1)$ & 2407(1) & $-132(1)$ & $33(1)$ \\
\hline$C(12)$ & $-1431(1)$ & 1397(1) & $94(1)$ & 33(1) \\
\hline C(13) & $-1101(1)$ & 1088(1) & 955(1) & 29(1) \\
\hline$C(14)$ & $-699(1)$ & 1786(1) & 1596(1) & $22(1)$ \\
\hline C(15) & $3304(1)$ & 2177(1) & 184(1) & $25(1)$ \\
\hline$C(16)$ & $4414(1)$ & 1451(1) & $61(1)$ & $37(1)$ \\
\hline $\mathrm{C}(17)$ & 2099(1) & 1541(1) & 202(1) & $35(1)$ \\
\hline$C(18)$ & $3245(1)$ & 2892(1) & $-635(1)$ & $32(1)$ \\
\hline C(19) & $4976(1)$ & 3398(1) & 1629(1) & $24(1)$ \\
\hline$C(20)$ & $5787(1)$ & 2487(1) & 1907(1) & $37(1)$ \\
\hline $\mathrm{C}(21)$ & 4897(1) & 4088(1) & $2458(1)$ & $35(1)$ \\
\hline$C(22)$ & 5631(1) & 3976(1) & $863(1)$ & $33(1)$ \\
\hline
\end{tabular}


Table 3. Bond lengths $[\AA]$ and angles $\left[^{\circ}\right]$ for $\mathbf{1 5 a}$.

\begin{tabular}{lc}
\hline $\mathrm{Si}(1)-\mathrm{O}(1)$ & $1.7040(8)$ \\
$\mathrm{Si}(1)-\mathrm{C}(3)$ & $1.8928(10)$ \\
$\mathrm{Si}(1)-\mathrm{C}(19)$ & $1.8976(11)$ \\
$\mathrm{Si}(1)-\mathrm{C}(15)$ & $1.9013(12)$ \\
$\mathrm{O}(1)-\mathrm{C}(1)$ & $1.3500(12)$ \\
$\mathrm{O}(2)-\mathrm{C}(1)$ & $1.2027(13)$ \\
$\mathrm{C}(1)-\mathrm{C}(2)$ & $1.5487(14)$ \\
$\mathrm{C}(2)-\mathrm{C}(5)$ & $1.5409(14)$ \\
$\mathrm{C}(2)-\mathrm{C}(3)$ & $1.5598(13)$ \\
$\mathrm{C}(2)-\mathrm{C}(6)$ & $1.5756(14)$ \\
$\mathrm{C}(3)-\mathrm{C}(4)$ & $1.5356(14)$ \\
$\mathrm{C}(6)-\mathrm{C}(7)$ & $1.5108(14)$ \\
$\mathrm{C}(6)-\mathrm{C}(9)$ & $1.5242(14)$ \\
$\mathrm{C}(7)-\mathrm{C}(8)$ & $1.3195(17)$ \\
$\mathrm{C}(9)-\mathrm{C}(10)$ & $1.3941(15)$ \\
$\mathrm{C}(9)-\mathrm{C}(14)$ & $1.3993(15)$ \\
$\mathrm{C}(10)-\mathrm{C}(11)$ & $1.3890(17)$ \\
$\mathrm{C}(11)-\mathrm{C}(12)$ & $1.3842(19)$ \\
$\mathrm{C}(12)-\mathrm{C}(13)$ & $1.3831(18)$ \\
$\mathrm{C}(13)-\mathrm{C}(14)$ & $1.3926(16)$ \\
$\mathrm{C}(15)-\mathrm{C}(16)$ & $1.5388(17)$ \\
$\mathrm{C}(15)-\mathrm{C}(17)$ & $1.5392(17)$ \\
$\mathrm{C}(15)-\mathrm{C}(18)$ & $1.5403(17)$ \\
$\mathrm{C}(19)-\mathrm{C}(21)$ & $1.5334(18)$ \\
$\mathrm{C}(19)-\mathrm{C}(22)$ & $1.5376(16)$ \\
$\mathrm{C}(19)-\mathrm{C}(20)$ & $1.5419(17)$ \\
$\mathrm{O}(1)-\mathrm{Si}(1)-\mathrm{C}(3)$ & $94.25(4)$ \\
$\mathrm{O}(1)-\mathrm{Si}(1)-\mathrm{C}(19)$ & $105.90(5)$ \\
$\mathrm{C}(3)-\mathrm{Si}(1)-\mathrm{C}(19)$ & $119.55(5)$ \\
$\mathrm{O}(1)-\mathrm{Si}(1)-\mathrm{C}(15)$ & $108.89(5)$ \\
$\mathrm{C}(3)-\mathrm{Si}(1)-\mathrm{C}(15)$ & $109.76(5)$ \\
$\mathrm{C}(19)-\mathrm{Si}(1)-\mathrm{C}(15)$ & $115.73(5)$ \\
&
\end{tabular}




$\begin{array}{ll}\mathrm{C}(1)-\mathrm{O}(1)-\mathrm{Si}(1) & 115.64(6) \\ \mathrm{O}(2)-\mathrm{C}(1)-\mathrm{O}(1) & 121.08(9) \\ \mathrm{O}(2)-\mathrm{C}(1)-\mathrm{C}(2) & 124.10(9) \\ \mathrm{O}(1)-\mathrm{C}(1)-\mathrm{C}(2) & 114.76(8) \\ \mathrm{C}(5)-\mathrm{C}(2)-\mathrm{C}(1) & 104.98(8) \\ \mathrm{C}(5)-\mathrm{C}(2)-\mathrm{C}(3) & 112.99(8) \\ \mathrm{C}(1)-\mathrm{C}(2)-\mathrm{C}(3) & 108.67(8) \\ \mathrm{C}(5)-\mathrm{C}(2)-\mathrm{C}(6) & 107.93(8) \\ \mathrm{C}(1)-\mathrm{C}(2)-\mathrm{C}(6) & 107.13(8) \\ \mathrm{C}(3)-\mathrm{C}(2)-\mathrm{C}(6) & 114.56(8) \\ \mathrm{C}(4)-\mathrm{C}(3)-\mathrm{C}(2) & 116.55(8) \\ \mathrm{C}(4)-\mathrm{C}(3)-\mathrm{Si}(1) & 118.17(7) \\ \mathrm{C}(2)-\mathrm{C}(3)-\mathrm{Si}(1) & 104.60(6) \\ \mathrm{C}(7)-\mathrm{C}(6)-\mathrm{C}(9) & 111.32(9) \\ \mathrm{C}(7)-\mathrm{C}(6)-\mathrm{C}(2) & 112.00(8) \\ \mathrm{C}(9)-\mathrm{C}(6)-\mathrm{C}(2) & 113.91(8) \\ \mathrm{C}(8)-\mathrm{C}(7)-\mathrm{C}(6) & 123.79(12) \\ \mathrm{C}(10)-\mathrm{C}(9)-\mathrm{C}(14) & 117.86(10) \\ \mathrm{C}(10)-\mathrm{C}(9)-\mathrm{C}(6) & 122.21(9) \\ \mathrm{C}(14)-\mathrm{C}(9)-\mathrm{C}(6) & 119.90(9) \\ \mathrm{C}(11)-\mathrm{C}(10)-\mathrm{C}(9) & 121.49(11) \\ \mathrm{C}(12)-\mathrm{C}(11)-\mathrm{C}(10) & 119.89(12) \\ \mathrm{C}(13)-\mathrm{C}(12)-\mathrm{C}(11) & 119.64(11) \\ \mathrm{C}(12)-\mathrm{C}(13)-\mathrm{C}(14) & 120.48(11) \\ \mathrm{C}(13)-\mathrm{C}(14)-\mathrm{C}(9) & 120.62(10) \\ \mathrm{C}(16)-\mathrm{C}(15)-\mathrm{C}(17) & 107.64(10) \\ \mathrm{C}(16)-\mathrm{C}(15)-\mathrm{C}(18) & 108.76(10) \\ \mathrm{C}(17)-\mathrm{C}(15)-\mathrm{C}(18) & 108.64(11) \\ \mathrm{C}(16)-\mathrm{C}(15)-\mathrm{Si}(1) & 114.68(9) \\ \mathrm{C}(17)-\mathrm{C}(15)-\mathrm{Si}(1) & 107.97(8) \\ \mathrm{C}(18)-\mathrm{C}(15)-\mathrm{Si}(1) & 109.00(8) \\ \mathrm{C}(21)-\mathrm{C}(19)-\mathrm{C}(22) & 108.53(11) \\ \mathrm{C}(21)-\mathrm{C}(19)-\mathrm{C}(20) & 106.69(11) \\ \mathrm{C}(22)-\mathrm{C}(19)-\mathrm{C}(20) & 109.32(10) \\ \mathrm{C}(21)-\mathrm{C}(19)-\mathrm{Si}(1) & 111.11(8)\end{array}$




$\begin{array}{ll}\mathrm{C}(22)-\mathrm{C}(19)-\mathrm{Si}(1) & 111.03(8) \\ \mathrm{C}(20)-\mathrm{C}(19)-\mathrm{Si}(1) & 110.05(9)\end{array}$

Table 4. Anisotropic displacement parameters $\left(\AA^{2} \times 10^{3}\right)$ for $15 a$. The anisotropic displacement factor exponent takes the form: $-2 \pi^{2}\left[h^{2} a^{* 2} U^{11}+\ldots+2 h k a^{*} b^{*} U^{12}\right]$

\begin{tabular}{|c|c|c|c|c|c|c|}
\hline & $\mathrm{U}^{11}$ & $\mathrm{U}^{22}$ & $\mathrm{U}^{33}$ & $\mathrm{U}^{23}$ & $\mathrm{U}^{13}$ & $\mathrm{U}^{12}$ \\
\hline $\operatorname{Si}(1)$ & $15(1)$ & $16(1)$ & $18(1)$ & 2(1) & $3(1)$ & $1(1)$ \\
\hline $\mathrm{O}(1)$ & $21(1)$ & 19(1) & $25(1)$ & $7(1)$ & $5(1)$ & $5(1)$ \\
\hline $\mathrm{O}(2)$ & $24(1)$ & $31(1)$ & 22(1) & 11(1) & $3(1)$ & $2(1)$ \\
\hline $\mathrm{C}(1)$ & $16(1)$ & $20(1)$ & $16(1)$ & $1(1)$ & $-2(1)$ & $-1(1)$ \\
\hline$C(2)$ & $15(1)$ & $16(1)$ & 15(1) & $0(1)$ & $0(1)$ & $1(1)$ \\
\hline $\mathrm{C}(3)$ & $16(1)$ & $16(1)$ & $15(1)$ & $1(1)$ & $0(1)$ & $-1(1)$ \\
\hline $\mathrm{C}(4)$ & $26(1)$ & $17(1)$ & $30(1)$ & $6(1)$ & $4(1)$ & $0(1)$ \\
\hline C(5) & $22(1)$ & $26(1)$ & 19(1) & $-6(1)$ & $-1(1)$ & $-2(1)$ \\
\hline C(6) & $15(1)$ & 19(1) & $18(1)$ & $0(1)$ & $1(1)$ & $1(1)$ \\
\hline $\mathrm{C}(7)$ & $19(1)$ & 21(1) & $32(1)$ & $-1(1)$ & $-3(1)$ & $2(1)$ \\
\hline$C(8)$ & $23(1)$ & $28(1)$ & $45(1)$ & $-10(1)$ & $-2(1)$ & $6(1)$ \\
\hline C(9) & $13(1)$ & 21(1) & $20(1)$ & $0(1)$ & $0(1)$ & $0(1)$ \\
\hline$C(10)$ & $26(1)$ & $25(1)$ & $26(1)$ & $3(1)$ & $-7(1)$ & $0(1)$ \\
\hline $\mathrm{C}(11)$ & $37(1)$ & $38(1)$ & $25(1)$ & 1(1) & $-13(1)$ & $-4(1)$ \\
\hline $\mathrm{C}(12)$ & $35(1)$ & $35(1)$ & 29(1) & $-6(1)$ & $-8(1)$ & $-11(1)$ \\
\hline $\mathrm{C}(13)$ & $32(1)$ & $24(1)$ & $31(1)$ & $-1(1)$ & $-1(1)$ & $-10(1)$ \\
\hline$C(14)$ & $22(1)$ & $23(1)$ & 21(1) & $3(1)$ & $0(1)$ & $-5(1)$ \\
\hline $\mathrm{C}(15)$ & $25(1)$ & $23(1)$ & $26(1)$ & $-5(1)$ & $8(1)$ & $0(1)$ \\
\hline$C(16)$ & $35(1)$ & $33(1)$ & $43(1)$ & $-9(1)$ & $13(1)$ & $7(1)$ \\
\hline$C(17)$ & $33(1)$ & $30(1)$ & $42(1)$ & $-17(1)$ & $10(1)$ & $-8(1)$ \\
\hline C(18) & $36(1)$ & $40(1)$ & 21(1) & $-4(1)$ & $4(1)$ & $0(1)$ \\
\hline $\mathrm{C}(19)$ & $15(1)$ & $31(1)$ & $26(1)$ & $5(1)$ & $-1(1)$ & $0(1)$ \\
\hline$C(20)$ & $24(1)$ & $47(1)$ & $42(1)$ & $12(1)$ & $-2(1)$ & $10(1)$ \\
\hline$C(21)$ & $22(1)$ & $51(1)$ & $32(1)$ & $-7(1)$ & $-6(1)$ & $-4(1)$ \\
\hline$C(22)$ & $21(1)$ & $43(1)$ & $35(1)$ & $9(1)$ & $0(1)$ & $-10(1)$ \\
\hline
\end{tabular}


Table 5. Hydrogen coordinates ( x 104) and isotropic displacement parameters $\left(\AA^{2} \mathrm{x} 10^{3}\right)$ for $15 a$.

\begin{tabular}{lrrrr}
\hline & $\mathrm{X}$ & $\mathrm{y}$ & $\mathrm{z}$ & $\mathrm{U}(\mathrm{eq})$ \\
& & & & \\
$\mathrm{H}(3)$ & & & & \\
$\mathrm{H}(4 \mathrm{~A})$ & $1461(12)$ & $3612(10)$ & $795(9)$ & $19(3)$ \\
$\mathrm{H}(4 \mathrm{~B})$ & $1514(15)$ & $5383(12)$ & $1078(10)$ & $35(4)$ \\
$\mathrm{H}(4 \mathrm{C})$ & $2647(15)$ & $5047(11)$ & $468(11)$ & $34(4)$ \\
$\mathrm{H}(5 \mathrm{~A})$ & $2851(14)$ & $5293(11)$ & $1507(10)$ & $32(4)$ \\
$\mathrm{H}(5 \mathrm{~B})$ & $2507(14)$ & $4430(11)$ & $3066(10)$ & $30(4)$ \\
$\mathrm{H}(5 \mathrm{C})$ & $1139(14)$ & $4199(11)$ & $3473(11)$ & $33(4)$ \\
$\mathrm{H}(6)$ & $1347(13)$ & $5095(11)$ & $2750(10)$ & $29(4)$ \\
$\mathrm{H}(7)$ & $-452(12)$ & $3319(10)$ & $2676(9)$ & $19(3)$ \\
$\mathrm{H}(8 \mathrm{~A})$ & $-532(14)$ & $4950(11)$ & $1411(11)$ & $36(4)$ \\
$\mathrm{H}(8 \mathrm{~B})$ & $-1958(15)$ & $5599(13)$ & $2374(11)$ & $41(4)$ \\
$\mathrm{H}(10)$ & $-1853(15)$ & $4590(12)$ & $3044(11)$ & $41(4)$ \\
$\mathrm{H}(11)$ & $-900(14)$ & $3808(12)$ & $335(10)$ & $35(4)$ \\
$\mathrm{H}(12)$ & $-1599(16)$ & $2639(13)$ & $-722(12)$ & $46(5)$ \\
$\mathrm{H}(13)$ & $-1723(16)$ & $923(13)$ & $-346(12)$ & $48(5)$ \\
$\mathrm{H}(14)$ & $-1141(14)$ & $376(12)$ & $1109(10)$ & $35(4)$ \\
$\mathrm{H}(16 \mathrm{~A})$ & $-498(13)$ & $1571(10)$ & $2195(9)$ & $23(3)$ \\
$\mathrm{H}(16 \mathrm{~B})$ & $5202(16)$ & $1798(13)$ & $-42(11)$ & $42(4)$ \\
$\mathrm{H}(16 \mathrm{C})$ & $4513(16)$ & $981(13)$ & $583(12)$ & $48(5)$ \\
$\mathrm{H}(17 \mathrm{~A})$ & $4257(16)$ & $1041(14)$ & $-487(13)$ & $52(5)$ \\
$\mathrm{H}(17 \mathrm{~B})$ & $1327(16)$ & $1956(12)$ & $252(11)$ & $40(4)$ \\
$\mathrm{H}(17 \mathrm{C})$ & $2026(15)$ & $1162(13)$ & $-351(12)$ & $45(4)$ \\
$\mathrm{H}(18 \mathrm{~A})$ & $2074(18)$ & $1050(15)$ & $712(13)$ & $58(5)$ \\
$\mathrm{H}(18 \mathrm{~B})$ & $3122(17)$ & $2484(14)$ & $-1174(13)$ & $50(5)$ \\
$\mathrm{H}(18 \mathrm{C})$ & $2522(16)$ & $3360(13)$ & $-580(11)$ & $43(4)$ \\
$\mathrm{H}(20 \mathrm{~A})$ & $4020(16)$ & $3285(13)$ & $-720(11)$ & $43(4)$ \\
$\mathrm{H}(20 \mathrm{~B})$ & $5980(18)$ & $2027(13)$ & $1430(13)$ & $50(5)$ \\
$\mathrm{H}(20 \mathrm{C})$ & $5354(17)$ & $2074(12)$ & $2349(12)$ & $45(5)$ \\
$\mathrm{H}(21 \mathrm{~A})$ & $6592(18)$ & $2737(13)$ & $2167(13)$ & $52(5)$ \\
& $4401(16)$ & $4723(13)$ & $2324(11)$ & $42(4)$ \\
& & & &
\end{tabular}




$\begin{array}{lrrrr}\mathrm{H}(21 \mathrm{~B}) & 4516(15) & 3748(12) & 2984(11) & 40(4) \\ \mathrm{H}(21 \mathrm{C}) & 5758(17) & 4282(13) & 2642(12) & 53(5) \\ \mathrm{H}(22 \mathrm{~A}) & 5151(16) & 4571(13) & 692(12) & 46(4) \\ \mathrm{H}(22 \mathrm{~B}) & 5743(15) & 3554(12) & 305(12) & 40(4) \\ \mathrm{H}(22 \mathrm{C}) & 6463(16) & 4180(13) & 1070(11) & 45(4)\end{array}$

Table 6. Torsion angles $\left[^{\circ}\right]$ for $\mathbf{1 5 a}$.

\begin{tabular}{|c|c|}
\hline $\mathrm{C}(3)-\mathrm{Si}(1)-\mathrm{O}(1)-\mathrm{C}(1)$ & $-6.69(8)$ \\
\hline $\mathrm{C}(19)-\mathrm{Si}(1)-\mathrm{O}(1)-\mathrm{C}(1)$ & 115.68(8) \\
\hline$C(15)-S i(1)-O(1)-C(1)$ & $-119.26(8)$ \\
\hline $\mathrm{Si}(1)-\mathrm{O}(1)-\mathrm{C}(1)-\mathrm{O}(2)$ & $-178.84(8)$ \\
\hline $\mathrm{Si}(1)-\mathrm{O}(1)-\mathrm{C}(1)-\mathrm{C}(2)$ & $-1.63(11)$ \\
\hline $\mathrm{O}(2)-\mathrm{C}(1)-\mathrm{C}(2)-\mathrm{C}(5)$ & $67.30(12)$ \\
\hline $\mathrm{O}(1)-\mathrm{C}(1)-\mathrm{C}(2)-\mathrm{C}(5)$ & $-109.82(10)$ \\
\hline $\mathrm{O}(2)-\mathrm{C}(1)-\mathrm{C}(2)-\mathrm{C}(3)$ & $-171.56(10)$ \\
\hline $\mathrm{O}(1)-\mathrm{C}(1)-\mathrm{C}(2)-\mathrm{C}(3)$ & $11.32(11)$ \\
\hline $\mathrm{O}(2)-\mathrm{C}(1)-\mathrm{C}(2)-\mathrm{C}(6)$ & $-47.27(13)$ \\
\hline $\mathrm{O}(1)-\mathrm{C}(1)-\mathrm{C}(2)-\mathrm{C}(6)$ & $135.61(9)$ \\
\hline$C(5)-C(2)-C(3)-C(4)$ & $-30.82(12)$ \\
\hline $\mathrm{C}(1)-\mathrm{C}(2)-\mathrm{C}(3)-\mathrm{C}(4)$ & $-146.91(9)$ \\
\hline$C(6)-C(2)-C(3)-C(4)$ & 93.33(10) \\
\hline$C(5)-C(2)-C(3)-S i(1)$ & 101.68(8) \\
\hline $\mathrm{C}(1)-\mathrm{C}(2)-\mathrm{C}(3)-\mathrm{Si}(1)$ & $-14.41(9)$ \\
\hline$C(6)-C(2)-C(3)-S i(1)$ & $-134.17(7)$ \\
\hline $\mathrm{O}(1)-\mathrm{Si}(1)-\mathrm{C}(3)-\mathrm{C}(4)$ & 143.83(8) \\
\hline $\mathrm{C}(19)-\mathrm{Si}(1)-\mathrm{C}(3)-\mathrm{C}(4)$ & $32.86(10)$ \\
\hline$C(15)-S i(1)-C(3)-C(4)$ & $-104.35(9)$ \\
\hline $\mathrm{O}(1)-\mathrm{Si}(1)-\mathrm{C}(3)-\mathrm{C}(2)$ & $12.26(7)$ \\
\hline$C(19)-S i(1)-C(3)-C(2)$ & $-98.71(7)$ \\
\hline$C(15)-S i(1)-C(3)-C(2)$ & $124.08(7)$ \\
\hline$C(5)-C(2)-C(6)-C(7)$ & $53.76(11)$ \\
\hline $\mathrm{C}(1)-\mathrm{C}(2)-\mathrm{C}(6)-\mathrm{C}(7)$ & 166.34(9) \\
\hline $\mathrm{C}(3)-\mathrm{C}(2)-\mathrm{C}(6)-\mathrm{C}(7)$ & $-73.05(11)$ \\
\hline$C(5)-C(2)-C(6)-C(9)$ & $-178.78(8)$ \\
\hline
\end{tabular}




\begin{tabular}{|c|c|}
\hline$C(1)-C(2)-C(6)-C(9)$ & $-66.20(10)$ \\
\hline $\mathrm{C}(3)-\mathrm{C}(2)-\mathrm{C}(6)-\mathrm{C}(9)$ & $54.41(11)$ \\
\hline$C(9)-C(6)-C(7)-C(8)$ & $110.68(13)$ \\
\hline$C(2)-C(6)-C(7)-C(8)$ & $-120.49(12)$ \\
\hline$C(7)-C(6)-C(9)-C(10)$ & $30.50(14)$ \\
\hline$C(2)-C(6)-C(9)-C(10)$ & $-97.30(11)$ \\
\hline$C(7)-C(6)-C(9)-C(14)$ & $-147.89(10)$ \\
\hline$C(2)-C(6)-C(9)-C(14)$ & 84.31(12) \\
\hline $\mathrm{C}(14)-\mathrm{C}(9)-\mathrm{C}(10)-\mathrm{C}(11)$ & $-0.16(17)$ \\
\hline $\mathrm{C}(6)-\mathrm{C}(9)-\mathrm{C}(10)-\mathrm{C}(11)$ & $-178.58(11)$ \\
\hline $\mathrm{C}(9)-\mathrm{C}(10)-\mathrm{C}(11)-\mathrm{C}(12)$ & $-0.9(2)$ \\
\hline $\mathrm{C}(10)-\mathrm{C}(11)-\mathrm{C}(12)-\mathrm{C}(13)$ & $0.8(2)$ \\
\hline C(11)-C(12)-C(13)-C(14) & $0.3(2)$ \\
\hline$C(12)-C(13)-C(14)-C(9)$ & $-1.42(18)$ \\
\hline $\mathrm{C}(10)-\mathrm{C}(9)-\mathrm{C}(14)-\mathrm{C}(13)$ & $1.32(16)$ \\
\hline$C(6)-C(9)-C(14)-C(13)$ & 179.77(10) \\
\hline $\mathrm{O}(1)-\mathrm{Si}(1)-\mathrm{C}(15)-\mathrm{C}(16)$ & $-82.03(9)$ \\
\hline C(3)-Si(1)-C(15)-C(16) & $176.07(9)$ \\
\hline C(19)-Si(1)-C(15)-C(16) & $37.07(11)$ \\
\hline $\mathrm{O}(1)-\mathrm{Si}(1)-\mathrm{C}(15)-\mathrm{C}(17)$ & $37.95(10)$ \\
\hline C(3)-Si(1)-C(15)-C(17) & $-63.95(10)$ \\
\hline $\mathrm{C}(19)-\mathrm{Si}(1)-\mathrm{C}(15)-\mathrm{C}(17)$ & 157.05(9) \\
\hline $\mathrm{O}(1)-\mathrm{Si}(1)-\mathrm{C}(15)-\mathrm{C}(18)$ & $155.80(8)$ \\
\hline C(3)-Si(1)-C(15)-C(18) & $53.90(9)$ \\
\hline$C(19)-S i(1)-C(15)-C(18)$ & $-85.10(9)$ \\
\hline $\mathrm{O}(1)-\mathrm{Si}(1)-\mathrm{C}(19)-\mathrm{C}(21)$ & $-63.89(10)$ \\
\hline C(3)-Si(1)-C(19)-C(21) & $40.59(10)$ \\
\hline $\mathrm{C}(15)-\mathrm{Si}(1)-\mathrm{C}(19)-\mathrm{C}(21)$ & 175.38(9) \\
\hline $\mathrm{O}(1)-\mathrm{Si}(1)-\mathrm{C}(19)-\mathrm{C}(22)$ & $175.22(8)$ \\
\hline C(3)-Si(1)-C(19)-C(22) & $-80.30(10)$ \\
\hline C(15)-Si(1)-C(19)-C(22) & $54.49(10)$ \\
\hline $\mathrm{O}(1)-\mathrm{Si}(1)-\mathrm{C}(19)-\mathrm{C}(20)$ & $54.05(9)$ \\
\hline C(3)-Si(1)-C(19)-C(20) & $158.53(8)$ \\
\hline$C(15)-S i(1)-C(19)-C(20)$ & $-66.68(10)$ \\
\hline
\end{tabular}




\section{B. Silalactone $15 b$.}

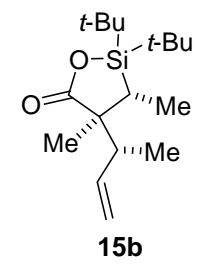

X-ray Data Collection, Structure Solution and Refinement for $\mathbf{1 5 b}$.

A colorless crystal of approximate dimensions $0.26 \times 0.32 \times 0.41 \mathrm{~mm}$ was mounted on a glass fiber and transferred to a Bruker CCD platform diffractometer. The SMART ${ }^{1}$ program package was used to determine the unit-cell parameters and for data collection (20 sec/frame scan time for a sphere of diffraction data). The raw frame data was processed using $\mathrm{SAINT}^{2}$ and $\mathrm{SADABS}^{3}$ to yield the reflection data file. Subsequent calculations were carried out using the SHELXTL ${ }^{4}$ program. The diffraction symmetry was $2 / m$ and the systematic absences were consistent with the centrosymmetric monoclinic space group $P 2_{1} / c$ which was later determined to be correct.

The structure was solved by direct methods and refined on $\mathrm{F}^{2}$ by full-matrix least-squares techniques. The analytical scattering factors ${ }^{5}$ for neutral atoms were used throughout the analysis. Hydrogen atoms were located from a difference-Fourier map and refined ( $x, y, z$ and $\mathrm{U}_{\text {iso }}$ ). At convergence, wR2 = 0.0980 and Goof $=1.069$ for 310 variables refined against 4324 data. As a comparison for refinement on F, R1 = 0.0356 for those 3760 data with $\mathrm{I}>2.0 \sigma(\mathrm{I})$.

References.

1. SMART Software Users Guide, Version 5.1, Bruker Analytical X-Ray Systems, Inc.; Madison, WI 1999.

2. SAINT Software Users Guide, Version 6.0, Bruker Analytical X-Ray Systems, Inc.; Madison, WI 1999.

3. Sheldrick, G. M. SADABS, Version 2.05, Bruker Analytical X-Ray Systems, Inc.; Madison, WI 2001.

4. Sheldrick, G. M. SHELXTL Version 6.12, Bruker Analytical X-Ray Systems, Inc.; Madison, WI 2001.

5. International Tables for X-Ray Crystallography 1992, Vol. C., Dordrecht: Kluwer AcademicPublishers. 


\section{Definitions:}

$\mathrm{wR} 2=\left[\Sigma\left[\mathrm{w}\left(\mathrm{F}_{\mathrm{o}}{ }^{2}-\mathrm{F}_{\mathrm{c}}{ }^{2}\right)^{2}\right] / \Sigma\left[\mathrm{w}\left(\mathrm{F}_{\mathrm{o}}{ }^{2}\right)^{2}\right]\right]^{1 / 2}$

$\mathrm{R} 1=\Sigma|| \mathrm{F}_{\mathrm{o}}|-| \mathrm{F}_{\mathrm{c}}|| / \Sigma\left|\mathrm{F}_{\mathrm{o}}\right|$

Goof $=\mathrm{S}=\left[\Sigma\left[\mathrm{w}\left(\mathrm{F}_{\mathrm{o}}^{2}-\mathrm{F}_{\mathrm{c}}^{2}\right)^{2}\right] /(\mathrm{n}-\mathrm{p})\right]^{1 / 2}$ where $\mathrm{n}$ is the number of reflections and $\mathrm{p}$ is the total number of parameters refined.

The thermal ellipsoid plot is shown at the $50 \%$ probability level.
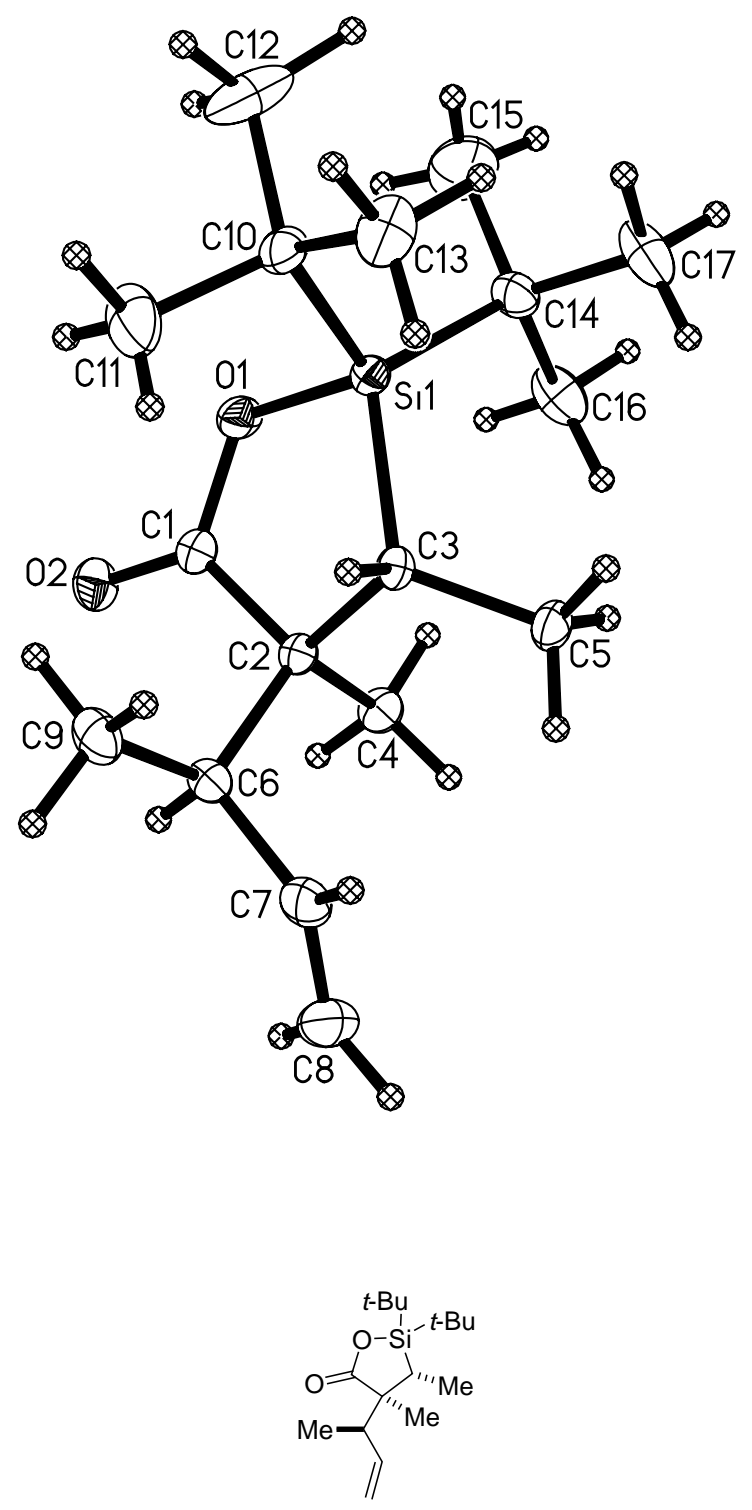
Table 1. Crystal data and structure refinement for $\mathbf{1 5 b}$.

Identification code

Empirical formula

Formula weight

Temperature

Wavelength

Crystal system

Space group

Unit cell dimensions

Volume

$\mathrm{Z}$

Density (calculated)

Absorption coefficient

$\mathrm{F}(000)$

Crystal size

Theta range for data collection

Index ranges

Reflections collected

Independent reflections

Completeness to theta $=28.31^{\circ}$

Absorption correction

Max. and min. transmission

Refinement method

Data / restraints / parameters

Goodness-of-fit on $\mathrm{F}^{2}$

Final R indices [I $>2$ sigma(I); 3760 data]

$\mathrm{R}$ indices (all data)

Extinction coefficient

Largest diff. peak and hole kaw67 (Stacie Calad)

$\mathrm{C}_{17} \mathrm{H}_{32} \mathrm{O}_{2} \mathrm{Si}$

296.52

158(2) K

$0.71073 \AA$

Monoclinic

$P 2{ }_{1} / C$

$\mathrm{a}=6.3526(8) \AA \quad \alpha=90^{\circ}$.

$\mathrm{b}=19.973(3) \AA$

$\beta=93.574(2)^{\circ}$.

c $=14.0526(17) \AA$

$\gamma=90^{\circ}$.

\section{6(4) $\AA^{3}$}

4

$1.107 \mathrm{Mg} / \mathrm{m}^{3}$

$0.133 \mathrm{~mm}^{-1}$

656

$0.41 \times 0.32 \times 0.26 \mathrm{~mm}^{3}$

1.77 to $28.31^{\circ}$.

$-8 \leq h \leq 8,-26 \leq k \leq 26,-18 \leq l \leq 18$

21369

4324 [R(int) $=0.0268]$

$97.6 \%$

Semi-empirical from equivalents

0.9663 and 0.9476

Full-matrix least-squares on $\mathrm{F}^{2}$

4324 / 0 / 310

1.069

$\mathrm{R} 1=0.0356, \mathrm{wR} 2=0.0905$

$\mathrm{R} 1=0.0434, \mathrm{wR} 2=0.0980$

0.0030(9)

0.388 and -0.269 e. $\AA^{-3}$ 
Table 2. Atomic coordinates ( x 104) and equivalent isotropic displacement parameters $\left(\AA^{2} \times 10^{3}\right)$ for $\mathbf{1 5 b}$. $U(\mathrm{eq})$ is defined as one third of the trace of the orthogonalized $U^{\mathrm{ij}}$ tensor.

\begin{tabular}{|c|c|c|c|c|}
\hline & $\mathrm{x}$ & $\mathrm{y}$ & $\mathrm{z}$ & $\mathrm{U}(\mathrm{eq})$ \\
\hline $\operatorname{Si}(1)$ & $2115(1)$ & $4058(1)$ & 2283(1) & $16(1)$ \\
\hline $\mathrm{O}(1)$ & $-243(1)$ & $4465(1)$ & 2156(1) & $20(1)$ \\
\hline $\mathrm{O}(2)$ & $-1633(1)$ & $5489(1)$ & $2167(1)$ & $23(1)$ \\
\hline $\mathrm{C}(1)$ & $-167(2)$ & $5127(1)$ & $2376(1)$ & $16(1)$ \\
\hline $\mathrm{C}(2)$ & $1860(2)$ & $5336(1)$ & 2965(1) & $14(1)$ \\
\hline $\mathrm{C}(3)$ & $3619(2)$ & $4808(1)$ & 2799(1) & $14(1)$ \\
\hline$C(4)$ & $1177(2)$ & 5335(1) & 3999(1) & $19(1)$ \\
\hline $\mathrm{C}(5)$ & $5244(2)$ & 4692(1) & $3640(1)$ & $20(1)$ \\
\hline $\mathrm{C}(6)$ & $2415(2)$ & $6071(1)$ & 2694(1) & 18(1) \\
\hline $\mathrm{C}(7)$ & $4245(2)$ & $6343(1)$ & 3313(1) & $26(1)$ \\
\hline $\mathrm{C}(8)$ & 4065(3) & $6774(1)$ & $4016(1)$ & $38(1)$ \\
\hline $\mathrm{C}(9)$ & 2861(2) & $6162(1)$ & $1644(1)$ & $24(1)$ \\
\hline$C(10)$ & $2886(2)$ & $3867(1)$ & $1026(1)$ & $22(1)$ \\
\hline $\mathrm{C}(11)$ & 2492(4) & 4498(1) & $429(1)$ & $48(1)$ \\
\hline $\mathrm{C}(12)$ & 1579(3) & $3300(1)$ & $534(1)$ & $46(1)$ \\
\hline C(13) & $5222(2)$ & $3679(1)$ & $1024(1)$ & $31(1)$ \\
\hline $\mathrm{C}(14)$ & $1747(2)$ & $3305(1)$ & 3089(1) & $23(1)$ \\
\hline$C(15)$ & $29(4)$ & 2830(1) & $2657(2)$ & $52(1)$ \\
\hline$C(16)$ & $994(2)$ & 3522(1) & $4060(1)$ & $30(1)$ \\
\hline $\mathrm{C}(17)$ & $3820(2)$ & 2918(1) & 3259(1) & $33(1)$ \\
\hline
\end{tabular}


Table 3. Bond lengths $[\AA]$ and angles $\left[{ }^{\circ}\right]$ for $\mathbf{1 5 b}$.

\begin{tabular}{lc}
\hline $\mathrm{Si}(1)-\mathrm{O}(1)$ & $1.7039(9)$ \\
$\mathrm{Si}(1)-\mathrm{C}(3)$ & $1.8966(11)$ \\
$\mathrm{Si}(1)-\mathrm{C}(10)$ & $1.9007(13)$ \\
$\mathrm{Si}(1)-\mathrm{C}(14)$ & $1.9063(13)$ \\
$\mathrm{O}(1)-\mathrm{C}(1)$ & $1.3569(14)$ \\
$\mathrm{O}(2)-\mathrm{C}(1)$ & $1.2019(14)$ \\
$\mathrm{C}(1)-\mathrm{C}(2)$ & $1.5441(15)$ \\
$\mathrm{C}(2)-\mathrm{C}(4)$ & $1.5418(15)$ \\
$\mathrm{C}(2)-\mathrm{C}(6)$ & $1.5618(15)$ \\
$\mathrm{C}(2)-\mathrm{C}(3)$ & $1.5650(15)$ \\
$\mathrm{C}(3)-\mathrm{C}(5)$ & $1.5372(15)$ \\
$\mathrm{C}(6)-\mathrm{C}(7)$ & $1.5083(17)$ \\
$\mathrm{C}(6)-\mathrm{C}(9)$ & $1.5303(16)$ \\
$\mathrm{C}(7)-\mathrm{C}(8)$ & $1.321(2)$ \\
$\mathrm{C}(10)-\mathrm{C}(11)$ & $1.525(2)$ \\
$\mathrm{C}(10)-\mathrm{C}(13)$ & $1.5313(18)$ \\
$\mathrm{C}(10)-\mathrm{C}(12)$ & $1.543(2)$ \\
$\mathrm{C}(14)-\mathrm{C}(17)$ & $1.5333(18)$ \\
$\mathrm{C}(14)-\mathrm{C}(16)$ & $1.5364(19)$ \\
$\mathrm{C}(14)-\mathrm{C}(15)$ & $1.542(2)$ \\
$\mathrm{O}(1)-\mathrm{Si}(1)-\mathrm{C}(3)$ & $94.69(4)$ \\
$\mathrm{O}(1)-\mathrm{Si}(1)-\mathrm{C}(10)$ & $105.93(5)$ \\
$\mathrm{C}(3)-\mathrm{Si}(1)-\mathrm{C}(10)$ & $111.19(5)$ \\
$\mathrm{O}(1)-\mathrm{Si}(1)-\mathrm{C}(14)$ & $107.40(5)$ \\
$\mathrm{C}(3)-\mathrm{Si}(1)-\mathrm{C}(14)$ & $118.25(5)$ \\
$\mathrm{C}(10)-\mathrm{Si}(1)-\mathrm{C}(14)$ & $116.23(6)$ \\
$\mathrm{C}(1)-\mathrm{O}(1)-\mathrm{Si}(1)$ & $114.98(7)$ \\
$\mathrm{O}(2)-\mathrm{C}(1)-\mathrm{O}(1)$ & $120.96(10)$ \\
$\mathrm{O}(2)-\mathrm{C}(1)-\mathrm{C}(2)$ & $125.14(10)$ \\
$\mathrm{O}(1)-\mathrm{C}(1)-\mathrm{C}(2)$ & $113.75(9)$ \\
$\mathrm{C}(4)-\mathrm{C}(2)-\mathrm{C}(1)$ & $103.28(8)$ \\
$\mathrm{C}(4)-\mathrm{C}(2)-\mathrm{C}(6)$ & $108.23(9)$ \\
&
\end{tabular}




$\begin{array}{ll}\mathrm{C}(1)-\mathrm{C}(2)-\mathrm{C}(6) & 108.53(9) \\ \mathrm{C}(4)-\mathrm{C}(2)-\mathrm{C}(3) & 112.58(9) \\ \mathrm{C}(1)-\mathrm{C}(2)-\mathrm{C}(3) & 108.47(9) \\ \mathrm{C}(6)-\mathrm{C}(2)-\mathrm{C}(3) & 115.03(9) \\ \mathrm{C}(5)-\mathrm{C}(3)-\mathrm{C}(2) & 116.03(9) \\ \mathrm{C}(5)-\mathrm{C}(3)-\mathrm{Si}(1) & 118.23(8) \\ \mathrm{C}(2)-\mathrm{C}(3)-\mathrm{Si}(1) & 104.00(7) \\ \mathrm{C}(7)-\mathrm{C}(6)-\mathrm{C}(9) & 109.30(10) \\ \mathrm{C}(7)-\mathrm{C}(6)-\mathrm{C}(2) & 112.05(9) \\ \mathrm{C}(9)-\mathrm{C}(6)-\mathrm{C}(2) & 113.84(9) \\ \mathrm{C}(8)-\mathrm{C}(7)-\mathrm{C}(6) & 124.49(14) \\ \mathrm{C}(11)-\mathrm{C}(10)-\mathrm{C}(13) & 109.15(14) \\ \mathrm{C}(11)-\mathrm{C}(10)-\mathrm{C}(12) & 107.12(14) \\ \mathrm{C}(13)-\mathrm{C}(10)-\mathrm{C}(12) & 108.23(12) \\ \mathrm{C}(11)-\mathrm{C}(10)-\mathrm{Si}(1) & 107.61(9) \\ \mathrm{C}(13)-\mathrm{C}(10)-\mathrm{Si}(1) & 110.91(8) \\ \mathrm{C}(12)-\mathrm{C}(10)-\mathrm{Si}(1) & 113.67(10) \\ \mathrm{C}(17)-\mathrm{C}(14)-\mathrm{C}(16) & 108.38(11) \\ \mathrm{C}(17)-\mathrm{C}(14)-\mathrm{C}(15) & 109.35(14) \\ \mathrm{C}(16)-\mathrm{C}(14)-\mathrm{C}(15) & 105.71(13) \\ \mathrm{C}(17)-\mathrm{C}(14)-\mathrm{Si}(1) & 110.79(9) \\ \mathrm{C}(16)-\mathrm{C}(14)-\mathrm{Si}(1) & 111.23(8) \\ \mathrm{C}(15)-\mathrm{C}(14)-\mathrm{Si}(1) & 111.22(10)\end{array}$


Table 4. Anisotropic displacement parameters $\left(\AA^{2} \times 10^{3}\right)$ for $\mathbf{1 5 b}$. The anisotropic displacement factor exponent takes the form: $-2 \pi^{2}\left[h^{2} a^{* 2} U^{11}+\ldots+2 h k a^{*} b^{*} U^{12}\right]$

\begin{tabular}{lcccccc}
\hline & $\mathrm{U}^{11}$ & $\mathrm{U}^{22}$ & $\mathrm{U}^{33}$ & $\mathrm{U}^{23}$ & $\mathrm{U}^{13}$ & $\mathrm{U}^{12}$ \\
\hline $\mathrm{Si}(1)$ & $16(1)$ & $16(1)$ & $16(1)$ & $-1(1)$ & $-1(1)$ & $1(1)$ \\
$\mathrm{O}(1)$ & $15(1)$ & $20(1)$ & $24(1)$ & $-4(1)$ & $-3(1)$ & $1(1)$ \\
$\mathrm{O}(2)$ & $16(1)$ & $26(1)$ & $26(1)$ & $1(1)$ & $0(1)$ & $5(1)$ \\
$\mathrm{C}(1)$ & $15(1)$ & $20(1)$ & $14(1)$ & $1(1)$ & $3(1)$ & $0(1)$ \\
$\mathrm{C}(2)$ & $14(1)$ & $16(1)$ & $13(1)$ & $0(1)$ & $2(1)$ & $0(1)$ \\
$\mathrm{C}(3)$ & $13(1)$ & $17(1)$ & $14(1)$ & $1(1)$ & $1(1)$ & $1(1)$ \\
$\mathrm{C}(4)$ & $22(1)$ & $22(1)$ & $14(1)$ & $-1(1)$ & $4(1)$ & $1(1)$ \\
$\mathrm{C}(5)$ & $16(1)$ & $23(1)$ & $20(1)$ & $1(1)$ & $-4(1)$ & $1(1)$ \\
$\mathrm{C}(6)$ & $20(1)$ & $16(1)$ & $18(1)$ & $1(1)$ & $3(1)$ & $1(1)$ \\
$\mathrm{C}(7)$ & $27(1)$ & $19(1)$ & $32(1)$ & $5(1)$ & $-3(1)$ & $-5(1)$ \\
$\mathrm{C}(8)$ & $54(1)$ & $26(1)$ & $32(1)$ & $0(1)$ & $-9(1)$ & $-12(1)$ \\
$\mathrm{C}(9)$ & $31(1)$ & $21(1)$ & $21(1)$ & $6(1)$ & $7(1)$ & $2(1)$ \\
$\mathrm{C}(10)$ & $24(1)$ & $25(1)$ & $18(1)$ & $-6(1)$ & $-2(1)$ & $6(1)$ \\
$\mathrm{C}(11)$ & $86(1)$ & $43(1)$ & $17(1)$ & $3(1)$ & $6(1)$ & $28(1)$ \\
$\mathrm{C}(12)$ & $34(1)$ & $67(1)$ & $37(1)$ & $-31(1)$ & $2(1)$ & $-9(1)$ \\
$\mathrm{C}(13)$ & $23(1)$ & $45(1)$ & $25(1)$ & $0(1)$ & $5(1)$ & $5(1)$ \\
$\mathrm{C}(14)$ & $25(1)$ & $17(1)$ & $27(1)$ & $2(1)$ & $0(1)$ & $-2(1)$ \\
$\mathrm{C}(15)$ & $64(1)$ & $35(1)$ & $54(1)$ & $7(1)$ & $-13(1)$ & $-28(1)$ \\
$\mathrm{C}(16)$ & $30(1)$ & $25(1)$ & $35(1)$ & $9(1)$ & $14(1)$ & $3(1)$ \\
$\mathrm{C}(17)$ & $39(1)$ & $27(1)$ & $35(1)$ & $10(1)$ & $13(1)$ & $14(1)$ \\
& & & & & & \\
\hline
\end{tabular}


Table 5. Hydrogen coordinates ( x 104) and isotropic displacement parameters $\left(\AA^{2} \mathrm{x} 10^{3}\right)$ for $\mathbf{1 5 b}$.

\begin{tabular}{|c|c|c|c|c|}
\hline & $\mathrm{x}$ & $\mathrm{y}$ & $\mathrm{z}$ & $\mathrm{U}(\mathrm{eq})$ \\
\hline $\mathrm{H}(3)$ & $4400(20)$ & 4973(7) & $2269(10)$ & $19(3)$ \\
\hline $\mathrm{H}(4 \mathrm{~A})$ & $680(20)$ & 4878(8) & 4183(11) & $23(4)$ \\
\hline $\mathrm{H}(4 \mathrm{~B})$ & $40(30)$ & $5664(8)$ & $4057(12)$ & $30(4)$ \\
\hline $\mathrm{H}(4 \mathrm{C})$ & $2370(30)$ & $5462(8)$ & $4432(12)$ & $27(4)$ \\
\hline $\mathrm{H}(5 \mathrm{~A})$ & $4680(20)$ & $4490(8)$ & 4198(11) & $25(4)$ \\
\hline $\mathrm{H}(5 \mathrm{~B})$ & $6340(20)$ & $4390(8)$ & $3443(11)$ & $25(4)$ \\
\hline $\mathrm{H}(5 \mathrm{C})$ & $5910(30)$ & 5102(9) & $3866(12)$ & $30(4)$ \\
\hline $\mathrm{H}(6)$ & $1180(20)$ & $6340(8)$ & 2832(11) & 23(4) \\
\hline $\mathrm{H}(7)$ & $5610(30)$ & $6204(8)$ & $3151(12)$ & $30(4)$ \\
\hline $\mathrm{H}(8 \mathrm{~A})$ & $5290(30)$ & 6922(10) & 4369(15) & $50(5)$ \\
\hline $\mathrm{H}(8 \mathrm{~B})$ & 2690(30) & 6943(10) & 4162(14) & 47(5) \\
\hline $\mathrm{H}(9 \mathrm{~A})$ & $1650(30)$ & $5984(8)$ & 1243(13) & $34(4)$ \\
\hline H(9B) & $2970(30)$ & 6644(9) & 1523(12) & $33(4)$ \\
\hline $\mathrm{H}(9 \mathrm{C})$ & $4120(30)$ & 5951(9) & 1501(13) & $36(5)$ \\
\hline $\mathrm{H}(11 \mathrm{~A})$ & $3400(30)$ & $4812(10)$ & 630(13) & $36(5)$ \\
\hline $\mathrm{H}(11 \mathrm{~B})$ & 2870(30) & $4420(10)$ & $-239(15)$ & $50(5)$ \\
\hline $\mathrm{H}(11 \mathrm{C})$ & $930(40)$ & 4660(13) & $415(18)$ & $78(8)$ \\
\hline $\mathrm{H}(12 \mathrm{~A})$ & $80(30)$ & $3381(10)$ & $551(15)$ & $57(6)$ \\
\hline $\mathrm{H}(12 \mathrm{~B})$ & 1930(30) & 3322(11) & $-139(16)$ & $61(6)$ \\
\hline $\mathrm{H}(12 \mathrm{C})$ & $2000(50)$ & $2800(15)$ & $860(20)$ & $102(10)$ \\
\hline $\mathrm{H}(13 \mathrm{~A})$ & $5630(30)$ & $3622(9)$ & $362(13)$ & $39(5)$ \\
\hline $\mathrm{H}(13 \mathrm{~B})$ & $5500(30)$ & $3254(10)$ & 1361(14) & $44(5)$ \\
\hline $\mathrm{H}(13 \mathrm{C})$ & $6150(30)$ & $4026(10)$ & 1331(15) & $50(6)$ \\
\hline $\mathrm{H}(15 \mathrm{~A})$ & $620(30)$ & 2633(11) & 2139(17) & $60(7)$ \\
\hline $\mathrm{H}(15 \mathrm{~B})$ & $-200(30)$ & 2462(11) & 3131(15) & $53(6)$ \\
\hline $\mathrm{H}(15 \mathrm{C})$ & $-1300(40)$ & $3042(13)$ & $2487(17)$ & $70(7)$ \\
\hline $\mathrm{H}(16 \mathrm{~A})$ & 2040(30) & 3806(9) & 4424(13) & $36(4)$ \\
\hline $\mathrm{H}(16 \mathrm{~B})$ & $-350(30)$ & 3758(9) & 4002(13) & 42(5) \\
\hline $\mathrm{H}(16 \mathrm{C})$ & $770(30)$ & $3116(9)$ & $4463(13)$ & $40(5)$ \\
\hline
\end{tabular}




$\begin{array}{lllll}\mathrm{H}(17 \mathrm{~A}) & 4960(30) & 3207(10) & 3542(13) & 41(5) \\ \mathrm{H}(17 \mathrm{~B}) & 3580(30) & 2534(9) & 3677(13) & 40(5) \\ \mathrm{H}(17 \mathrm{C}) & 4270(30) & 2732(11) & 2649(16) & 59(6)\end{array}$


Table 6. Torsion angles $\left[{ }^{\circ}\right]$ for $\mathbf{1 5 b}$.

\begin{tabular}{lc}
\hline $\mathrm{C}(3)-\mathrm{Si}(1)-\mathrm{O}(1)-\mathrm{C}(1)$ & $4.61(8)$ \\
$\mathrm{C}(10)-\mathrm{Si}(1)-\mathrm{O}(1)-\mathrm{C}(1)$ & $-109.00(8)$ \\
$\mathrm{C}(14)-\mathrm{Si}(1)-\mathrm{O}(1)-\mathrm{C}(1)$ & $126.16(8)$ \\
$\mathrm{Si}(1)-\mathrm{O}(1)-\mathrm{C}(1)-\mathrm{O}(2)$ & $167.45(9)$ \\
$\mathrm{Si}(1)-\mathrm{O}(1)-\mathrm{C}(1)-\mathrm{C}(2)$ & $-16.69(11)$ \\
$\mathrm{O}(2)-\mathrm{C}(1)-\mathrm{C}(2)-\mathrm{C}(4)$ & $78.45(13)$ \\
$\mathrm{O}(1)-\mathrm{C}(1)-\mathrm{C}(2)-\mathrm{C}(4)$ & $-97.21(10)$ \\
$\mathrm{O}(2)-\mathrm{C}(1)-\mathrm{C}(2)-\mathrm{C}(6)$ & $-36.27(14)$ \\
$\mathrm{O}(1)-\mathrm{C}(1)-\mathrm{C}(2)-\mathrm{C}(6)$ & $148.07(9)$ \\
$\mathrm{O}(2)-\mathrm{C}(1)-\mathrm{C}(2)-\mathrm{C}(3)$ & $-161.89(10)$ \\
$\mathrm{O}(1)-\mathrm{C}(1)-\mathrm{C}(2)-\mathrm{C}(3)$ & $22.45(12)$ \\
$\mathrm{C}(4)-\mathrm{C}(2)-\mathrm{C}(3)-\mathrm{C}(5)$ & $-35.15(13)$ \\
$\mathrm{C}(1)-\mathrm{C}(2)-\mathrm{C}(3)-\mathrm{C}(5)$ & $-148.81(9)$ \\
$\mathrm{C}(6)-\mathrm{C}(2)-\mathrm{C}(3)-\mathrm{C}(5)$ & $89.47(12)$ \\
$\mathrm{C}(4)-\mathrm{C}(2)-\mathrm{C}(3)-\mathrm{Si}(1)$ & $96.49(9)$ \\
$\mathrm{C}(1)-\mathrm{C}(2)-\mathrm{C}(3)-\mathrm{Si}(1)$ & $-17.18(9)$ \\
$\mathrm{C}(6)-\mathrm{C}(2)-\mathrm{C}(3)-\mathrm{Si}(1)$ & $-138.89(8)$ \\
$\mathrm{O}(1)-\mathrm{Si}(1)-\mathrm{C}(3)-\mathrm{C}(5)$ & $138.46(9)$ \\
$\mathrm{C}(10)-\mathrm{Si}(1)-\mathrm{C}(3)-\mathrm{C}(5)$ & $-112.44(9)$ \\
$\mathrm{C}(14)-\mathrm{Si}(1)-\mathrm{C}(3)-\mathrm{C}(5)$ & $25.83(10)$ \\
$\mathrm{O}(1)-\mathrm{Si}(1)-\mathrm{C}(3)-\mathrm{C}(2)$ & $8.12(7)$ \\
$\mathrm{C}(10)-\mathrm{Si}(1)-\mathrm{C}(3)-\mathrm{C}(2)$ & $117.22(7)$ \\
$\mathrm{C}(14)-\mathrm{Si}(1)-\mathrm{C}(3)-\mathrm{C}(2)$ & $-104.50(8)$ \\
$\mathrm{C}(4)-\mathrm{C}(2)-\mathrm{C}(6)-\mathrm{C}(7)$ & $62.43(12)$ \\
$\mathrm{C}(1)-\mathrm{C}(2)-\mathrm{C}(6)-\mathrm{C}(7)$ & $173.87(10)$ \\
$\mathrm{C}(3)-\mathrm{C}(2)-\mathrm{C}(6)-\mathrm{C}(7)$ & $-64.44(13)$ \\
$\mathrm{C}(4)-\mathrm{C}(2)-\mathrm{C}(6)-\mathrm{C}(9)$ & $-172.90(10)$ \\
$\mathrm{C}(1)-\mathrm{C}(2)-\mathrm{C}(6)-\mathrm{C}(9)$ & $-61.46(12)$ \\
$\mathrm{C}(3)-\mathrm{C}(2)-\mathrm{C}(6)-\mathrm{C}(9)$ & $60.23(13)$ \\
$\mathrm{C}(9)-\mathrm{C}(6)-\mathrm{C}(7)-\mathrm{C}(8)$ & $128.74(14)$ \\
$\mathrm{C}(2)-\mathrm{C}(6)-\mathrm{C}(7)-\mathrm{C}(8)$ & $-104.11(15)$ \\
$\mathrm{O}(1)-\mathrm{Si}(1)-\mathrm{C}(10)-\mathrm{C}(11)$ & $45.04(13)$ \\
$\mathrm{C}(3)-\mathrm{Si}(1)-\mathrm{C}(10)-\mathrm{C}(11)$ & $-56.61(13)$ \\
& \\
& \\
& \\
&
\end{tabular}




$\begin{array}{lc}\text { C(14)-Si(1)-C(10)-C(11) } & 164.20(12) \\ \text { O(1)-Si(1)-C(10)-C(13) } & 164.36(9) \\ \text { C(3)-Si(1)-C(10)-C(13) } & 62.72(11) \\ \text { C(14)-Si(1)-C(10)-C(13) } & -76.47(11) \\ \text { O(1)-Si(1)-C(10)-C(12) } & -73.41(12) \\ \text { C(3)-Si(1)-C(10)-C(12) } & -175.06(11) \\ \text { C(14)-Si(1)-C(10)-C(12) } & 45.76(13) \\ \text { O(1)-Si(1)-C(14)-C(17) } & -178.68(9) \\ \text { C(3)-Si(1)-C(14)-C(17) } & -73.28(11) \\ \text { C(10)-Si(1)-C(14)-C(17) } & 62.95(11) \\ \text { O(1)-Si(1)-C(14)-C(16) } & -58.07(10) \\ \text { C(3)-Si(1)-C(14)-C(16) } & 47.33(11) \\ \text { C(10)-Si(1)-C(14)-C(16) } & -176.44(9) \\ \text { O(1)-Si(1)-C(14)-C(15) } & 59.47(14) \\ \text { C(3)-Si(1)-C(14)-C(15) } & 164.87(12) \\ \text { C(10)-Si(1)-C(14)-C(15) } & -58.90(14)\end{array}$

\section{Selected Spectra}




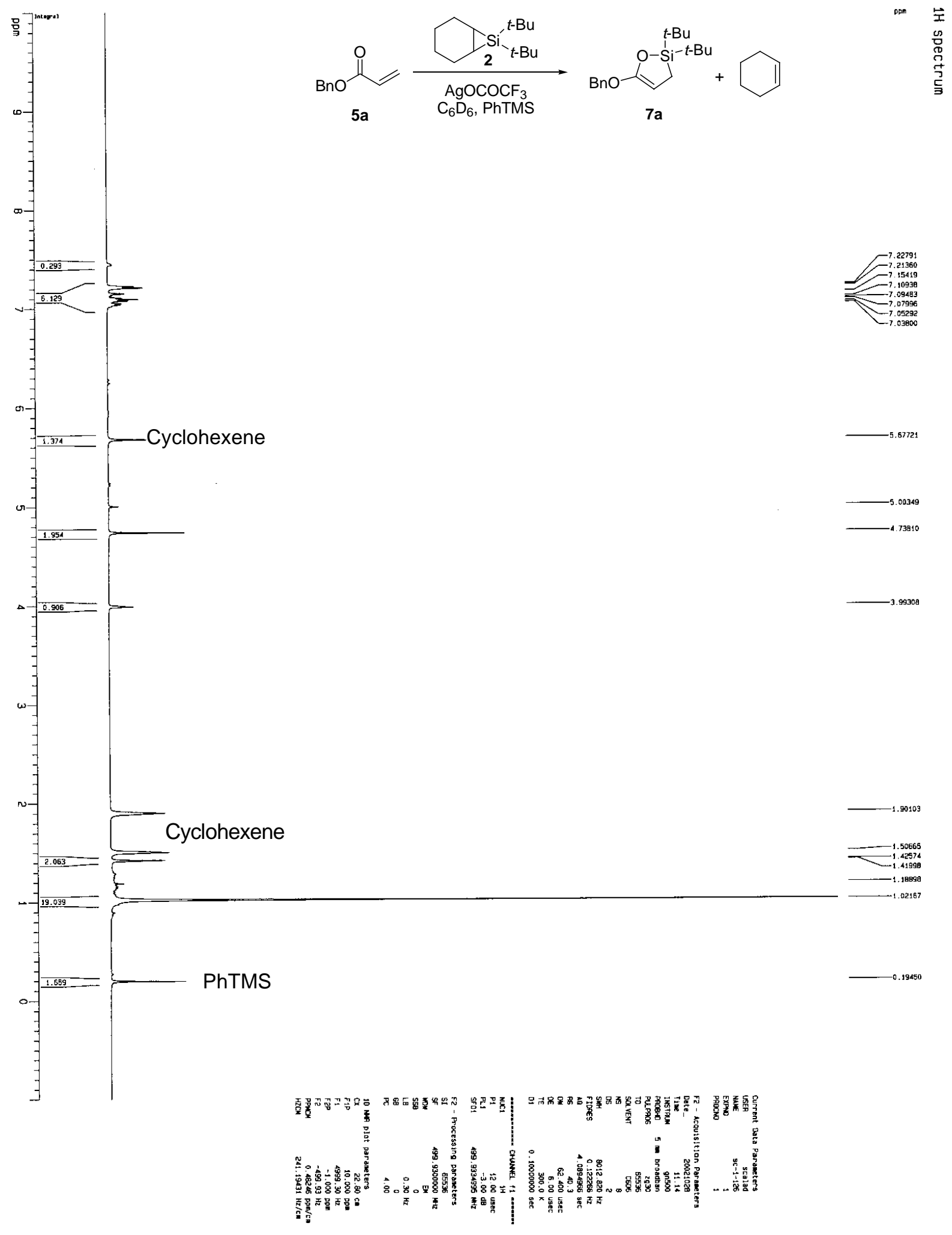




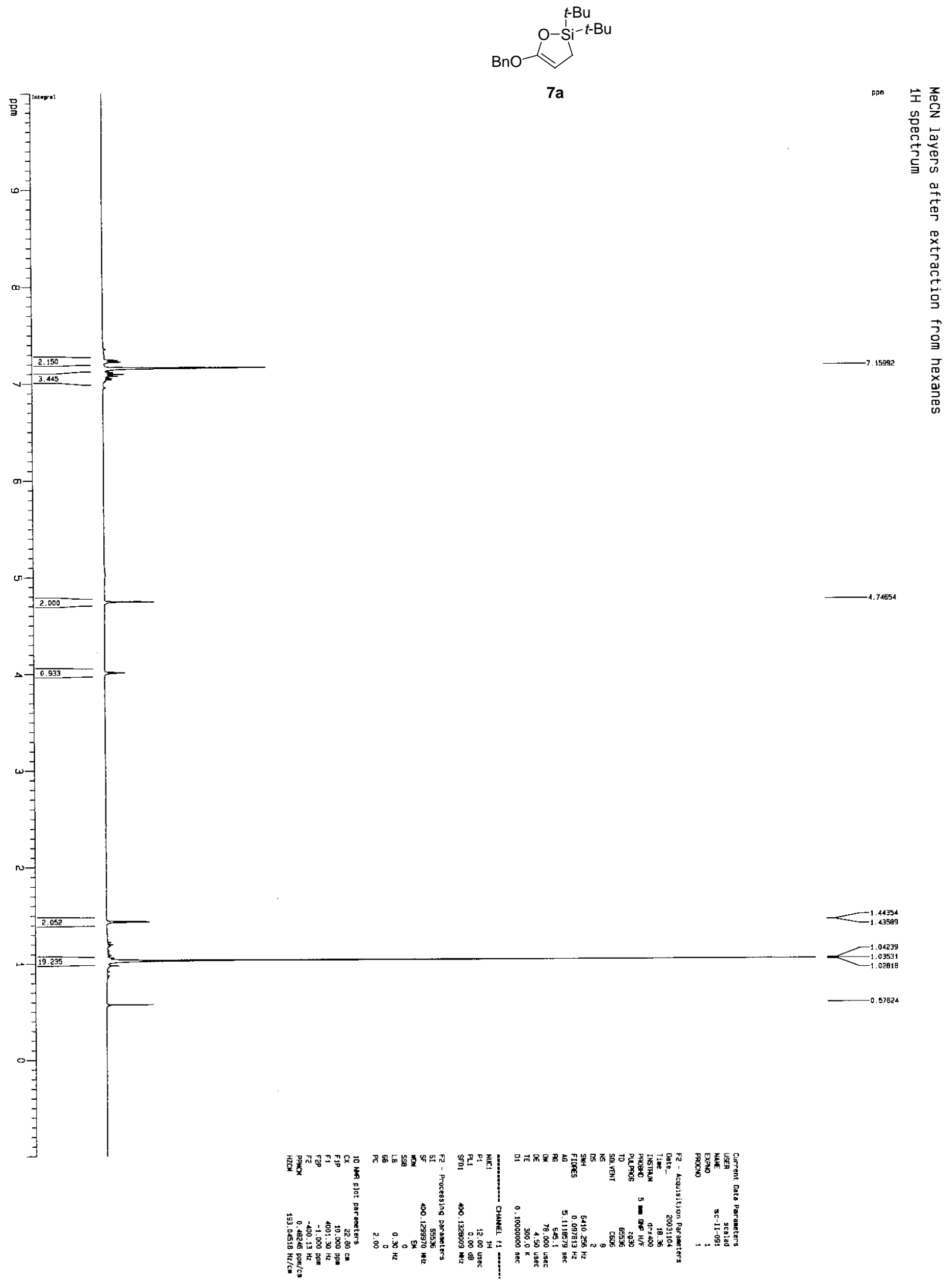




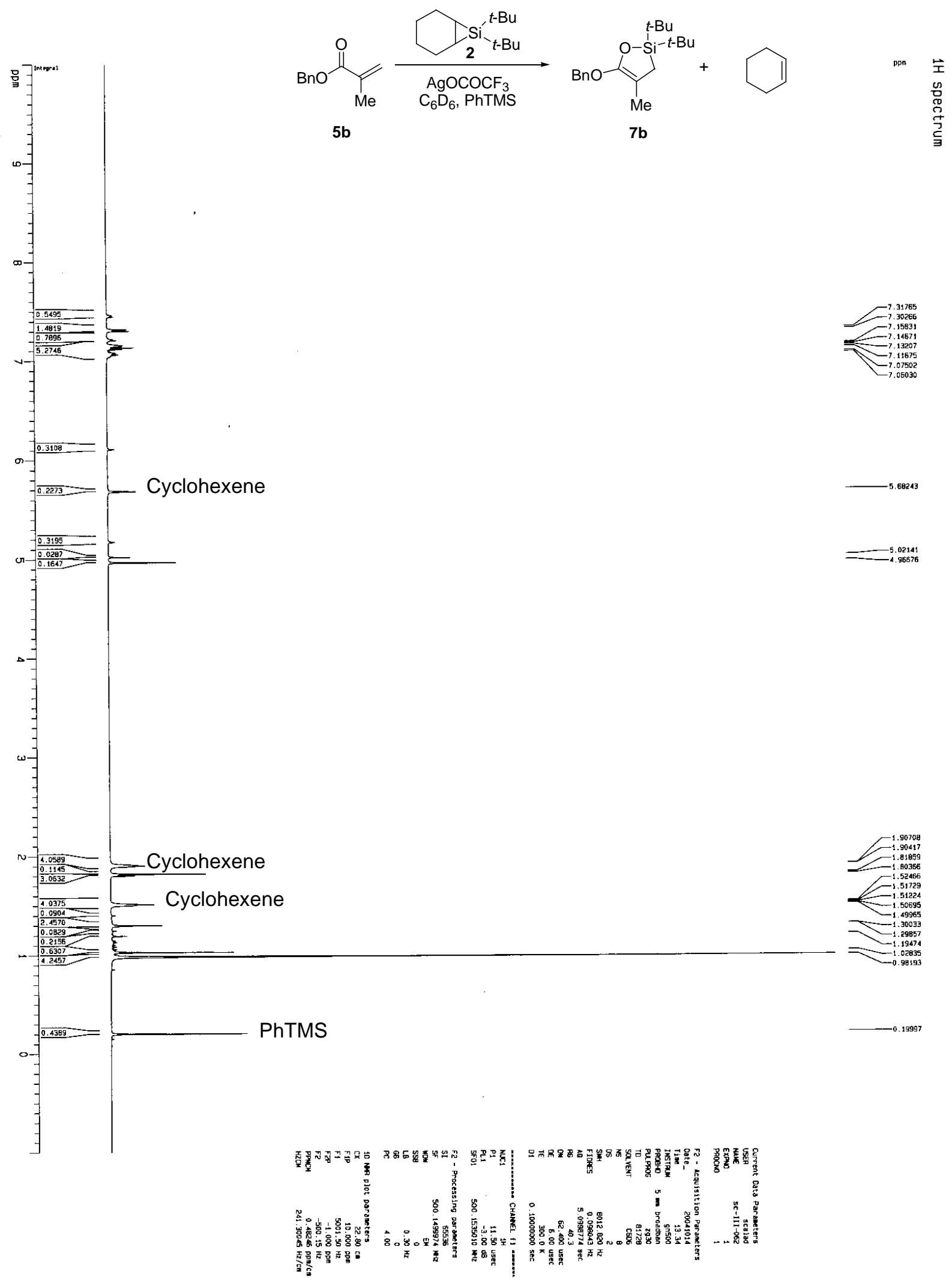




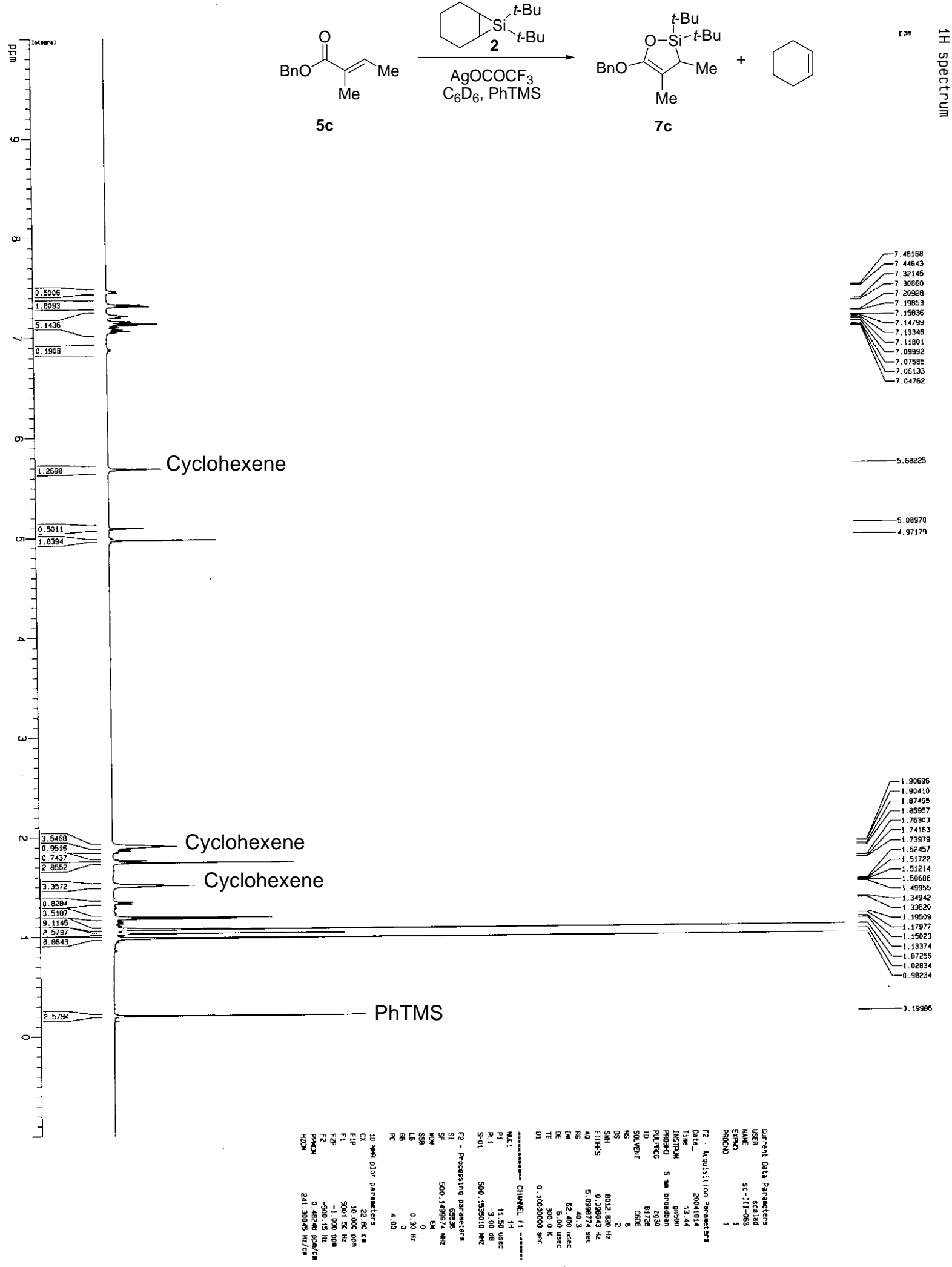




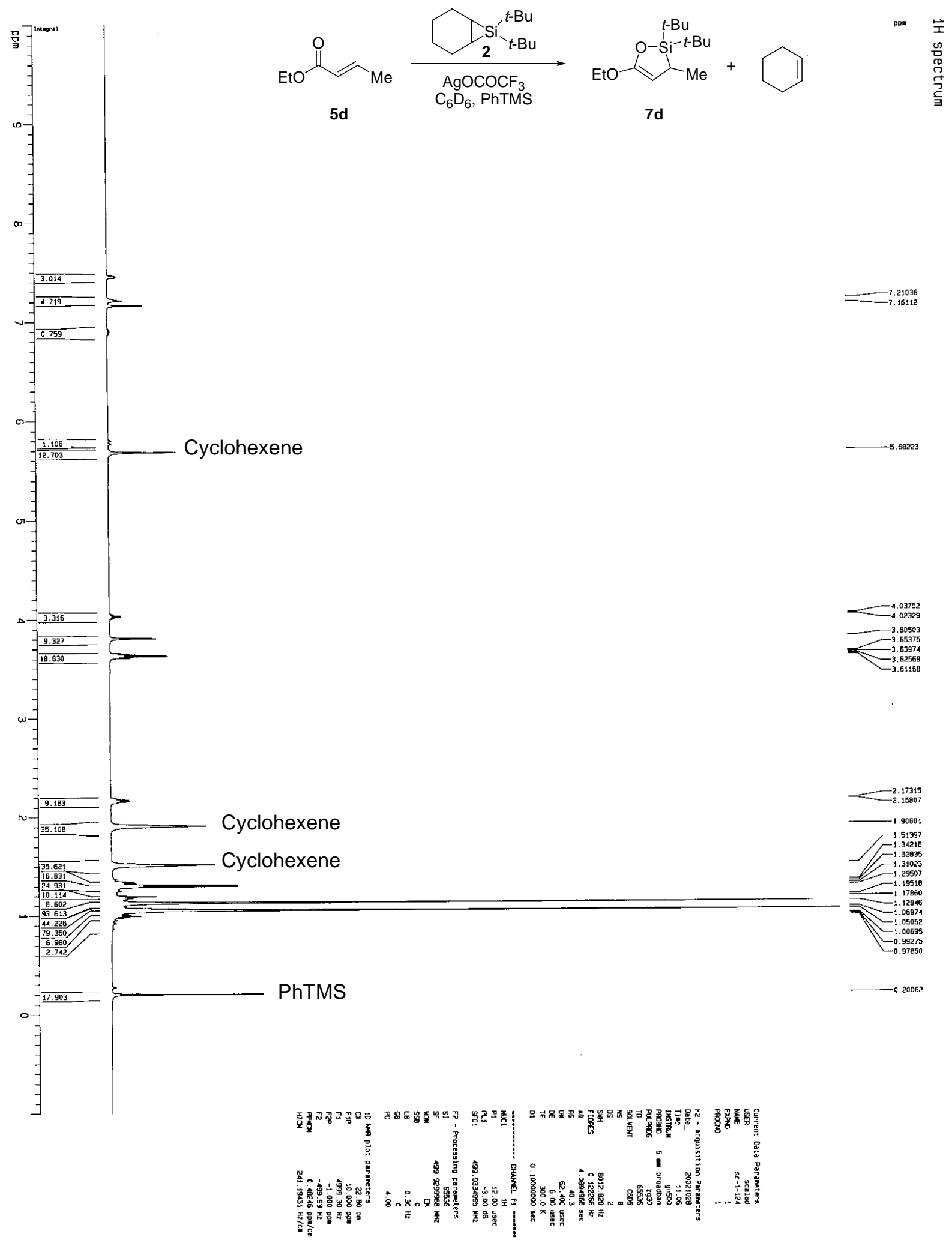




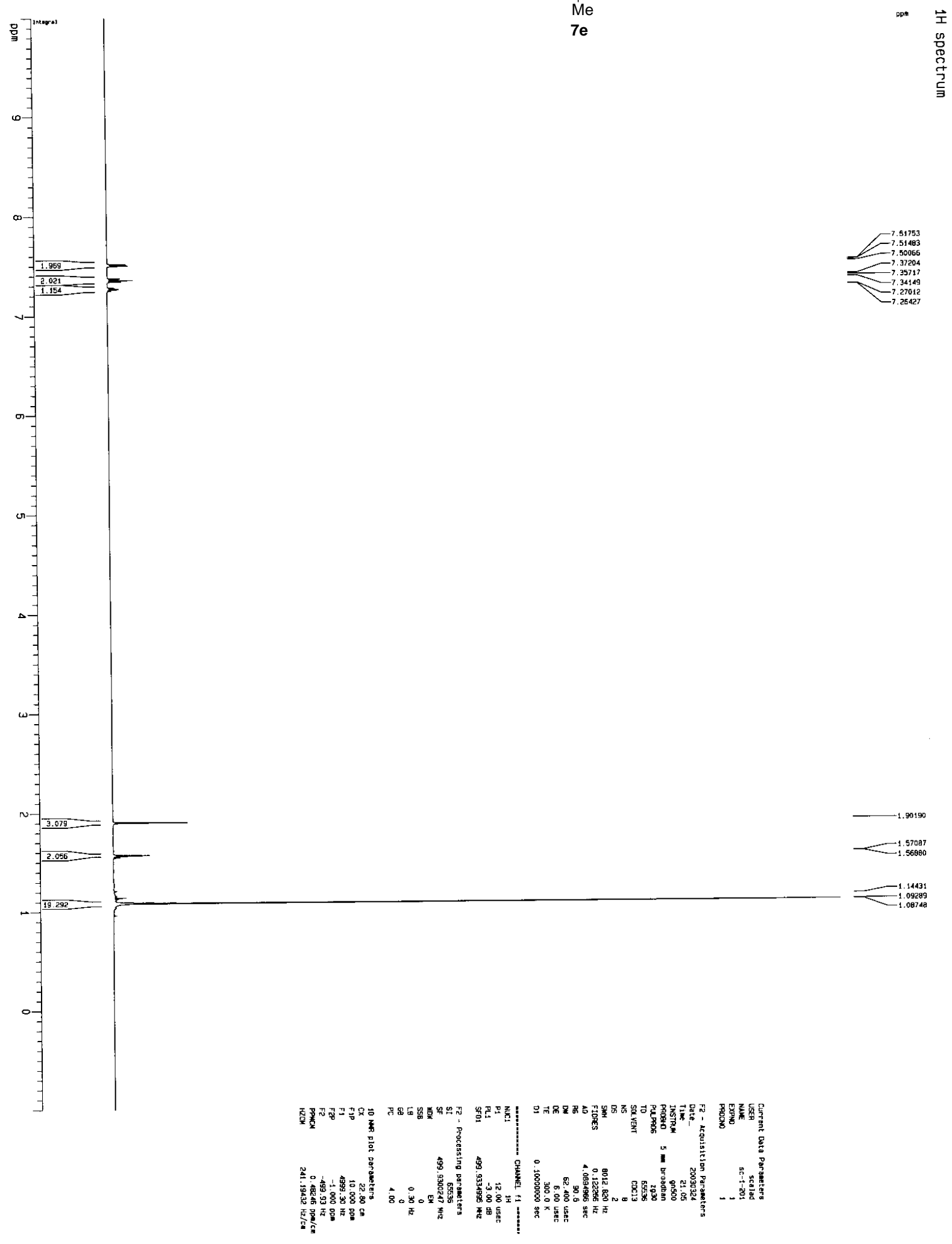




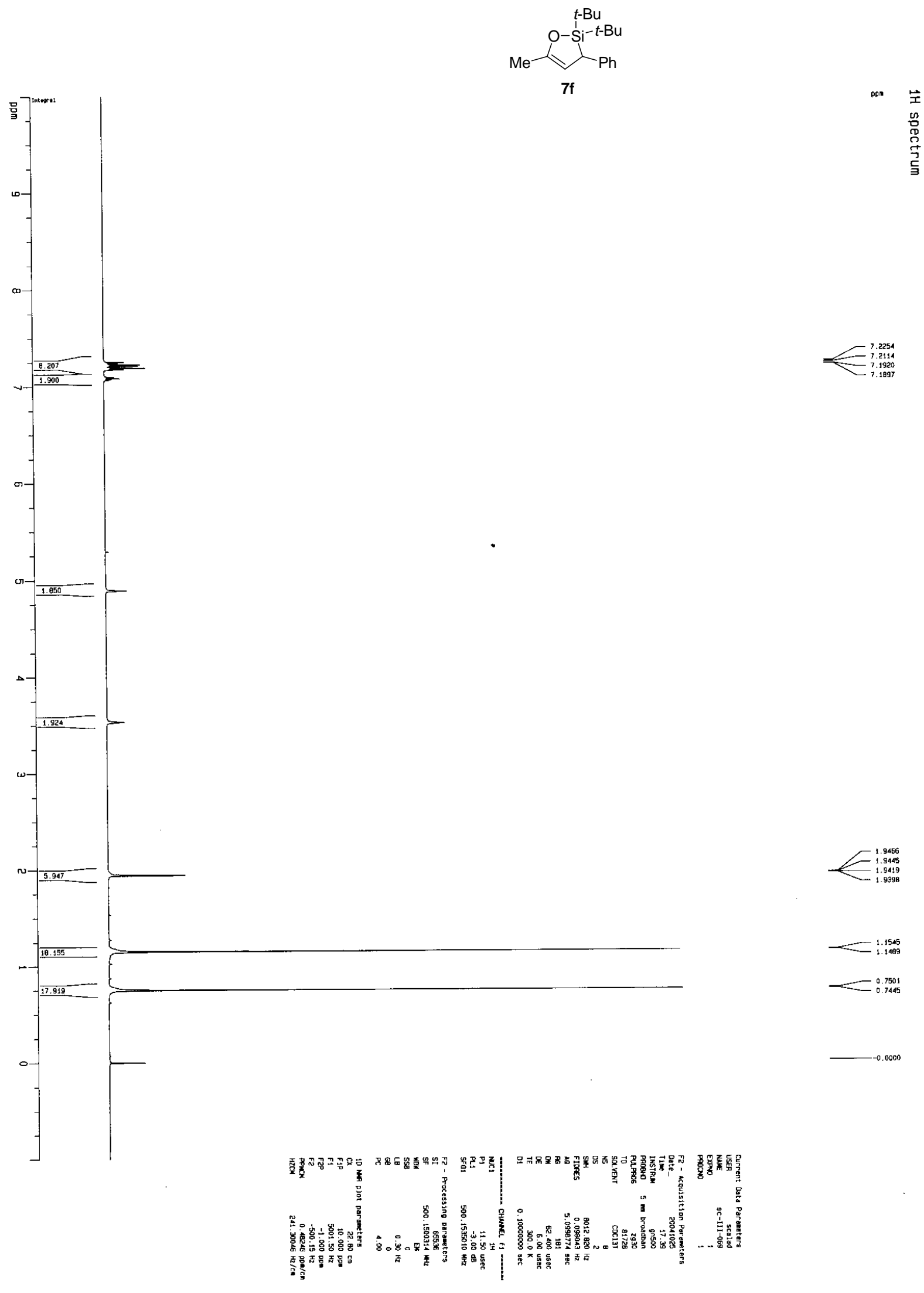



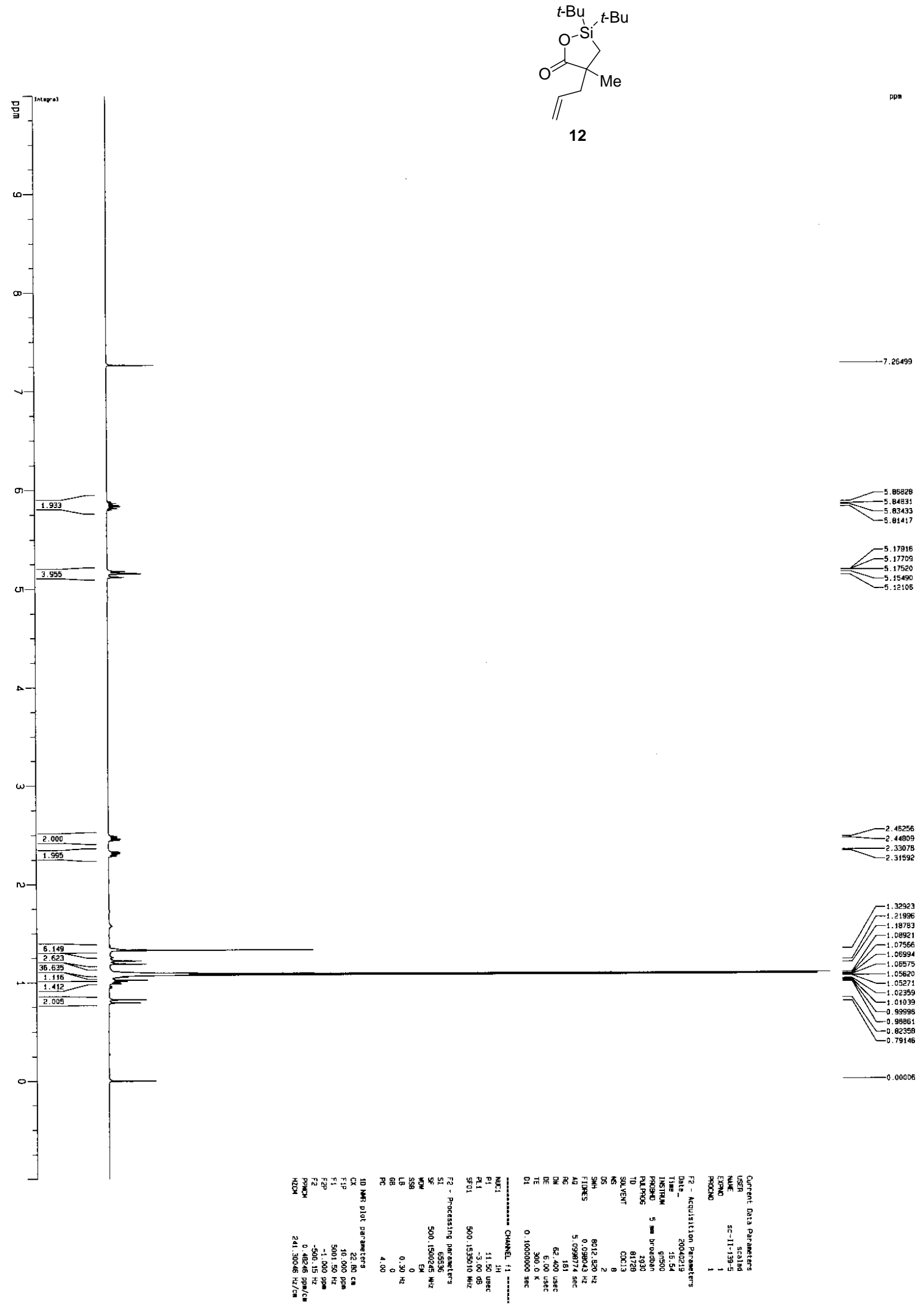


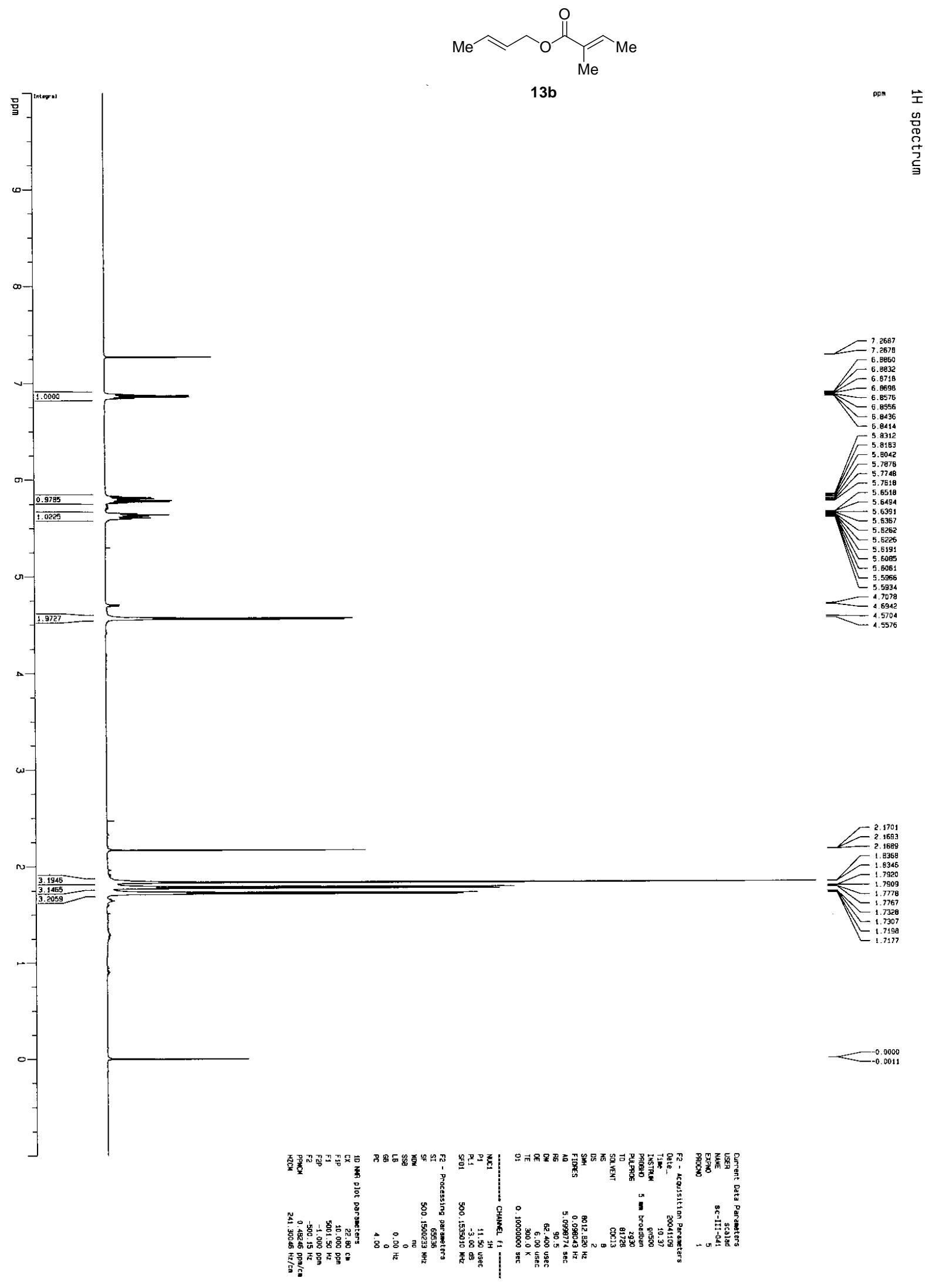




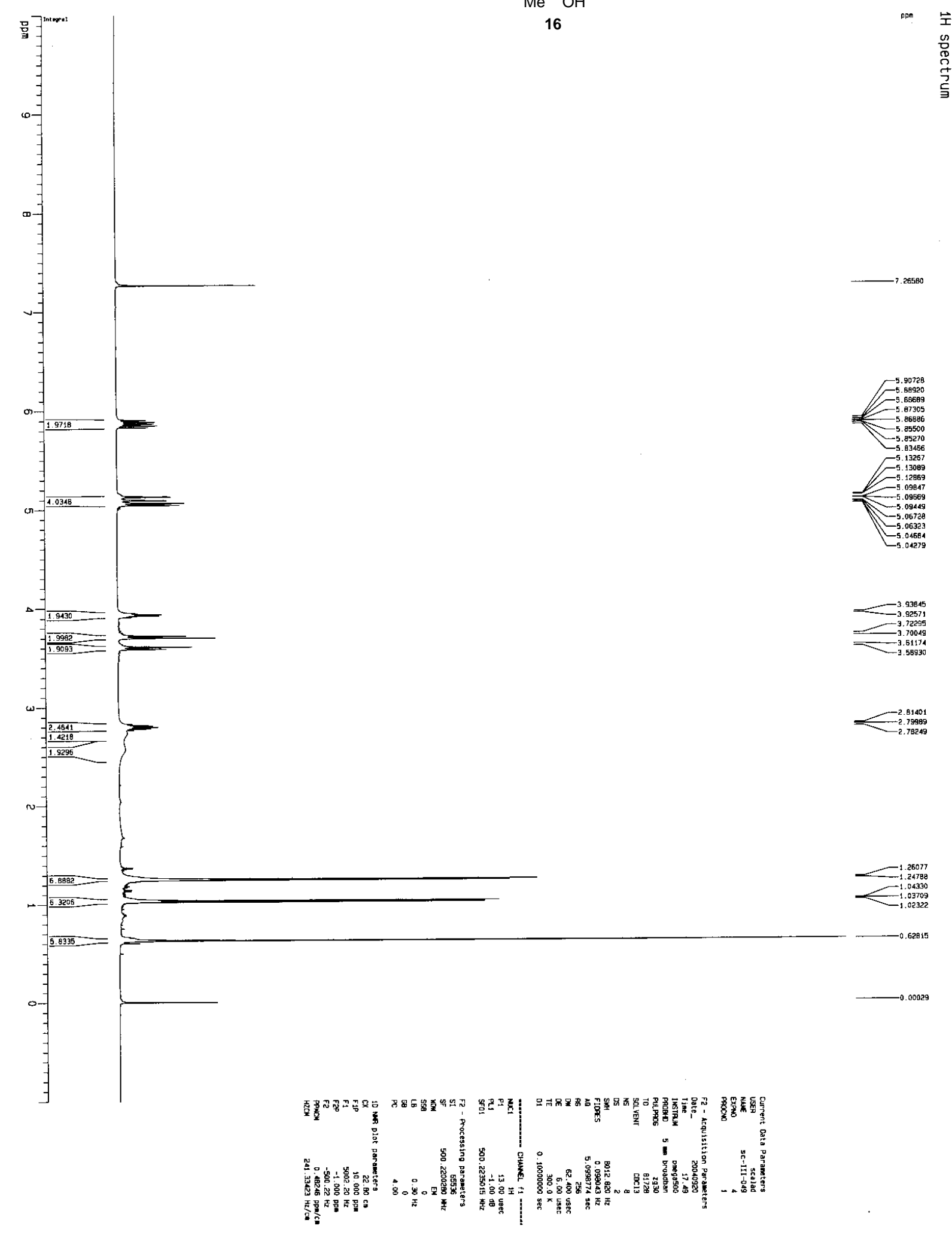




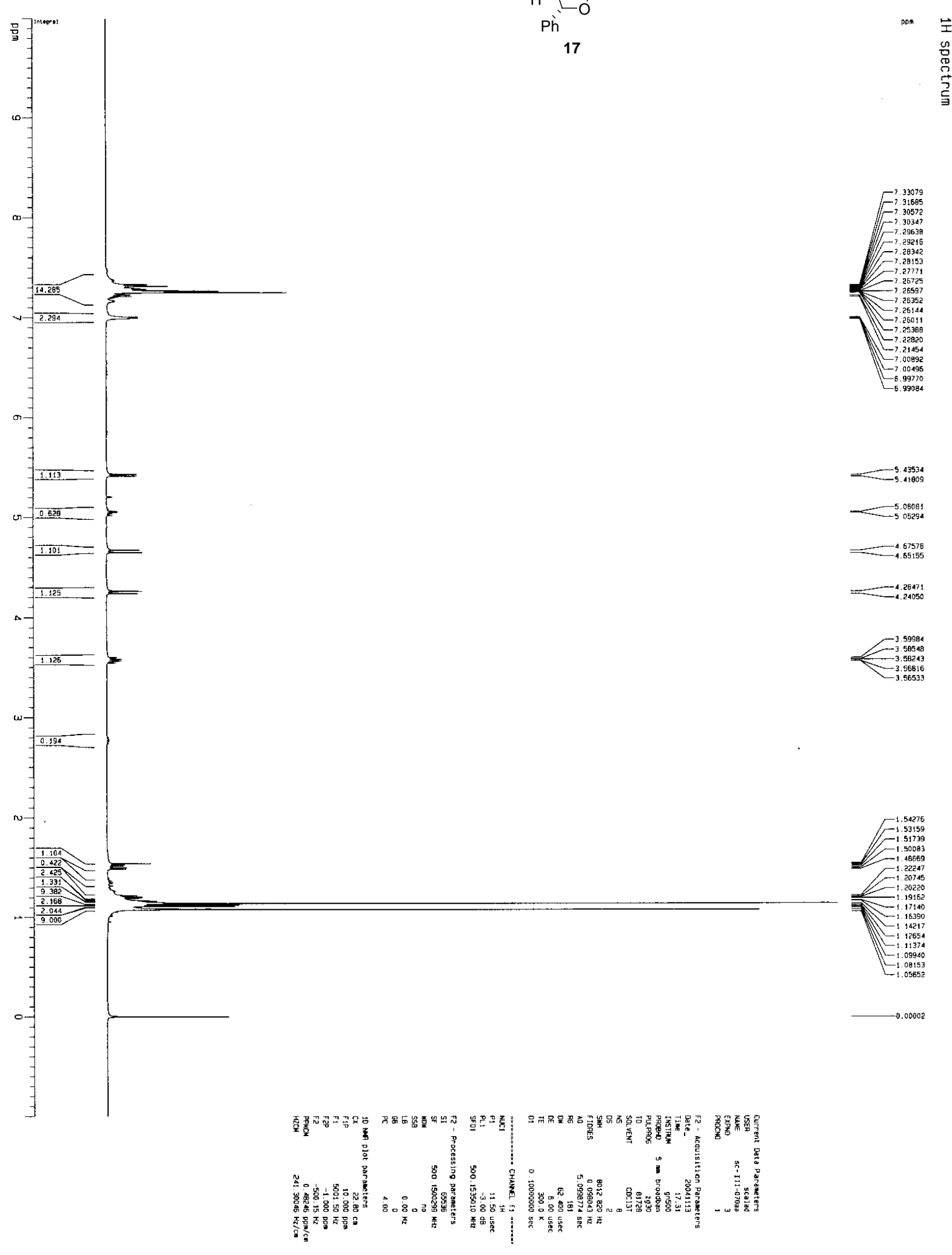




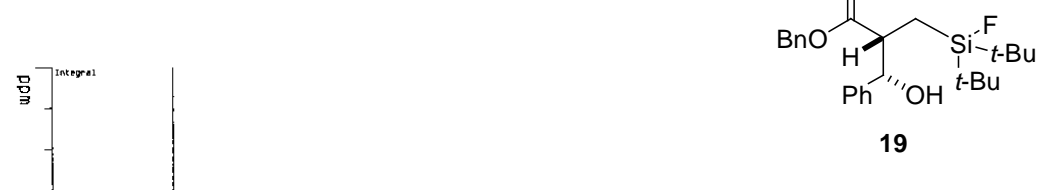


Data File C: \HPCHEM \I\DATA \SAC \SCIO02A.D
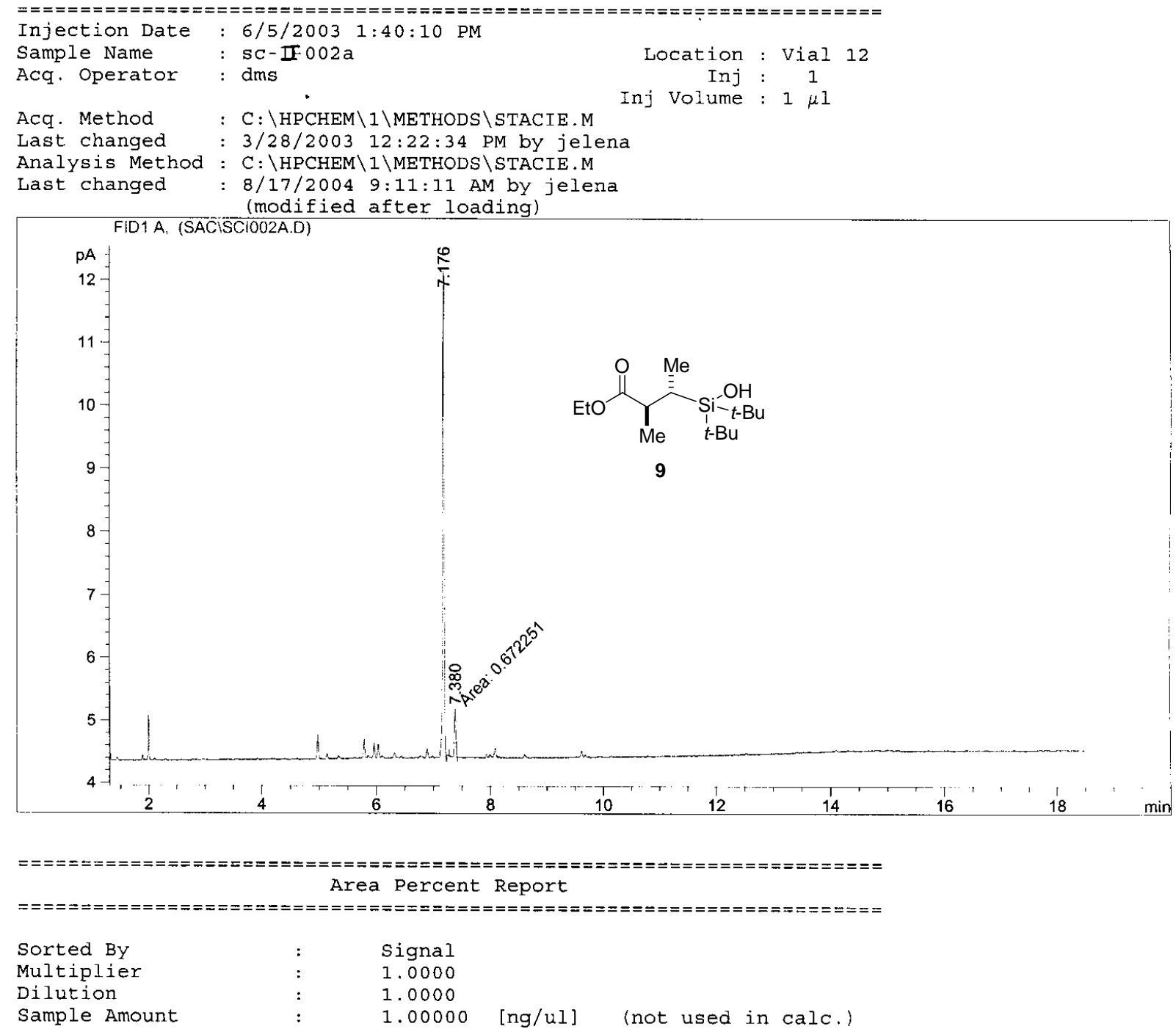

Signal 1: FID1 A,
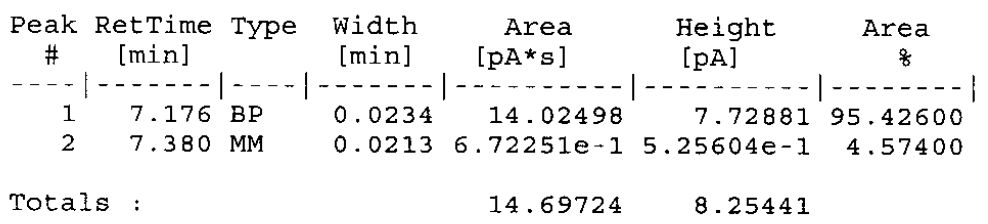

Results obtained with enhanced integrator!

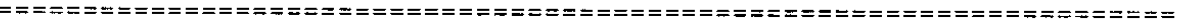

$\star * *$ End of Report *** 
Data File C: $\backslash$ HPCHEM $\backslash 1 \backslash D A T A \backslash S A C \backslash S C 2206 C R$.D

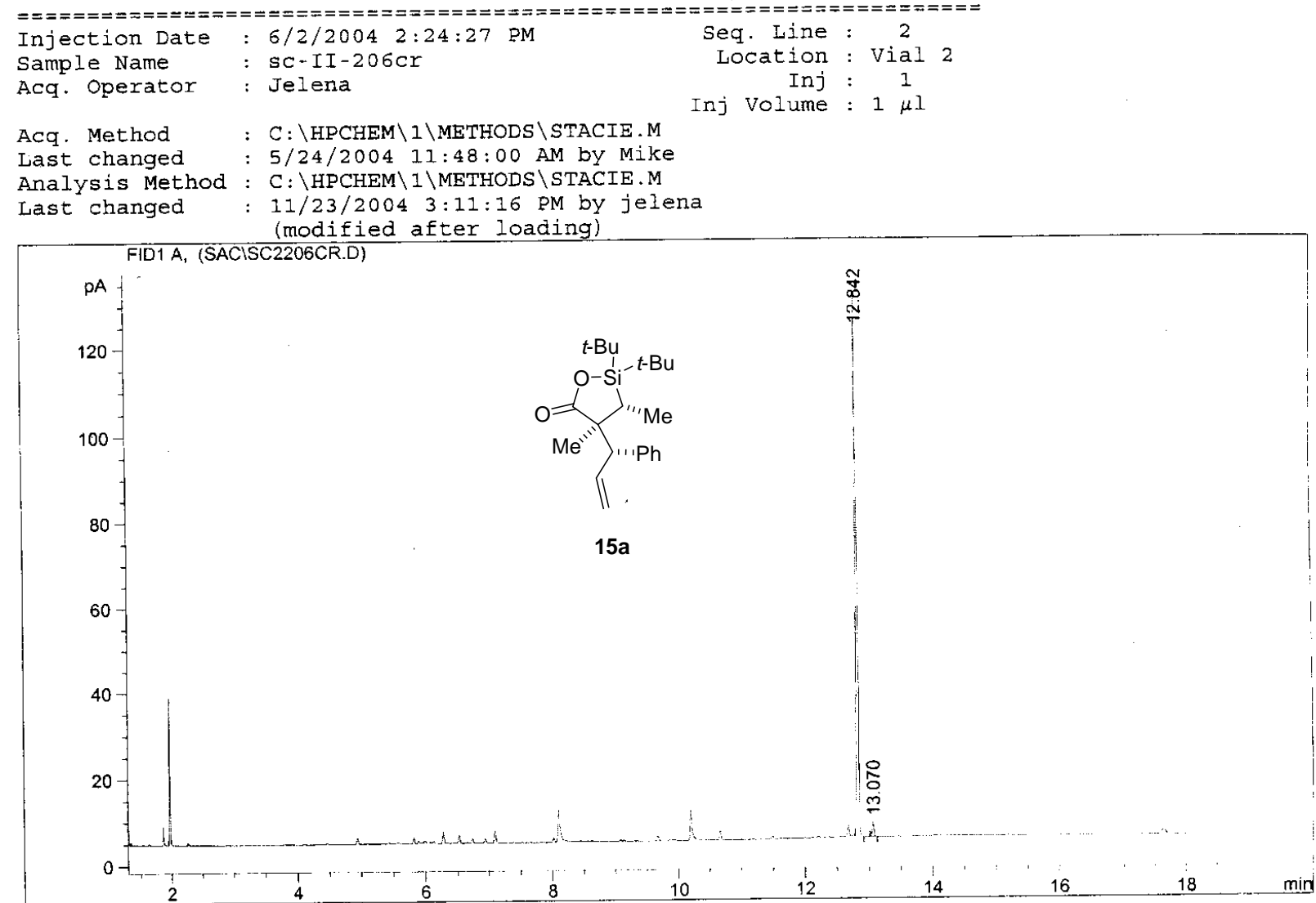

\begin{tabular}{|c|c|c|c|c|}
\hline Sorted BY & $:$ & Signal & & \\
\hline Multiplier & $:$ & 1.0000 & & \\
\hline Dilution & $:$ & 1.0000 & & \\
\hline Signal 1: FIDI A, & & & & 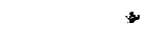 \\
\hline $\begin{array}{l}\text { Peak RetTime Type } \\
\text { \# [min] }\end{array}$ & $\begin{array}{l}\text { Width } \\
\text { [min] }\end{array}$ & $\begin{array}{r}\text { Area } \\
{\left[\mathrm{pA}^{*} \mathrm{~s}\right]}\end{array}$ & $\begin{array}{l}\text { Height } \\
{\left[p^{A}\right]}\end{array}$ & $\underset{\frac{7}{6}}{\operatorname{Area}}$ \\
\hline $1 \quad 12.842 \mathrm{BP}$ & 0.0258 & 227.61867 & 125.98470 & 97.04901 \\
\hline $213.070 \mathrm{BP}$ & 0.0276 & 6.92124 & 3.58025 & 2.95099 \\
\hline Totals : & & 234.53991 & 129.56495 & \\
\hline
\end{tabular}




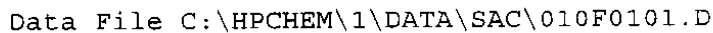

rxn start time $3: 40$
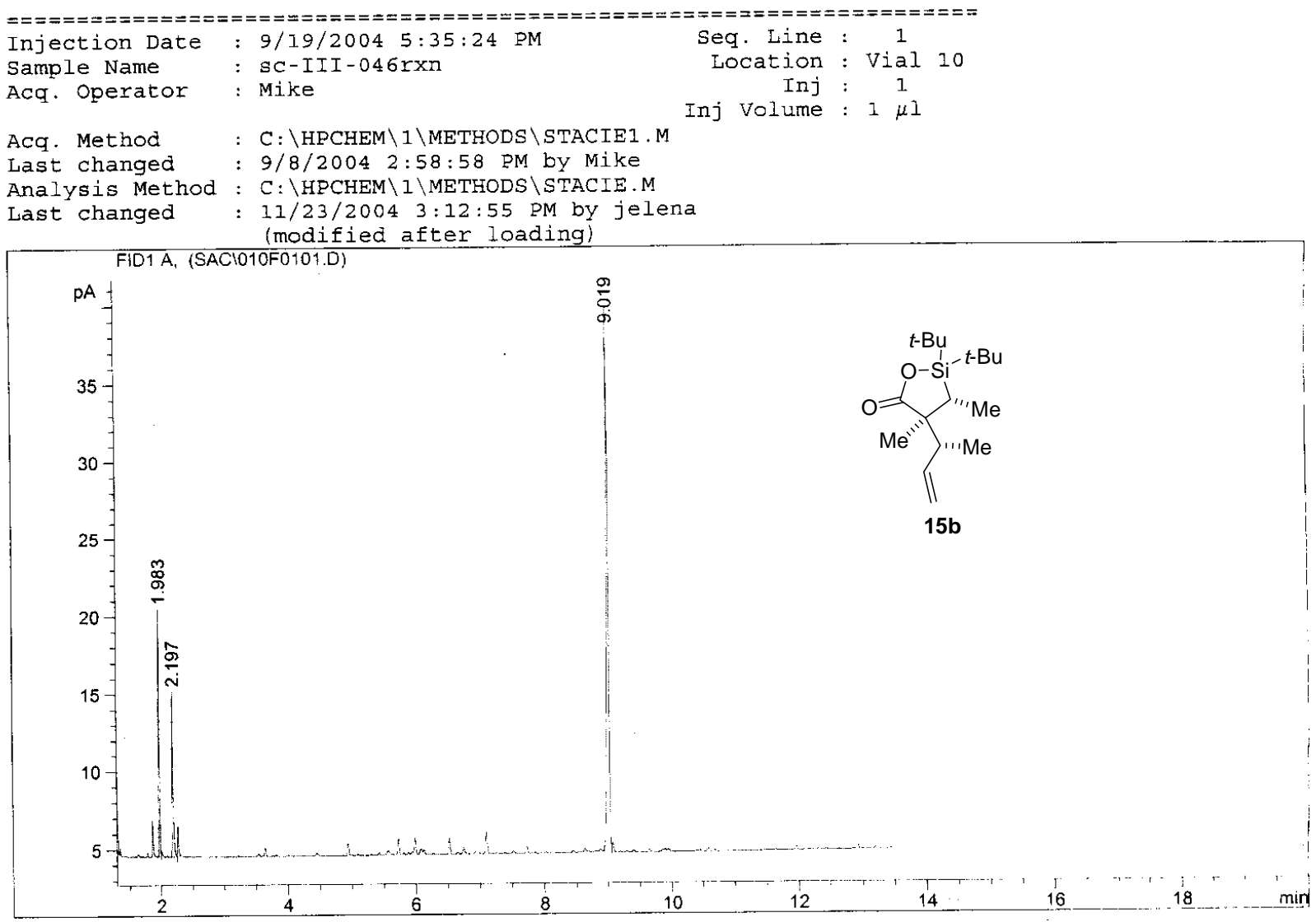

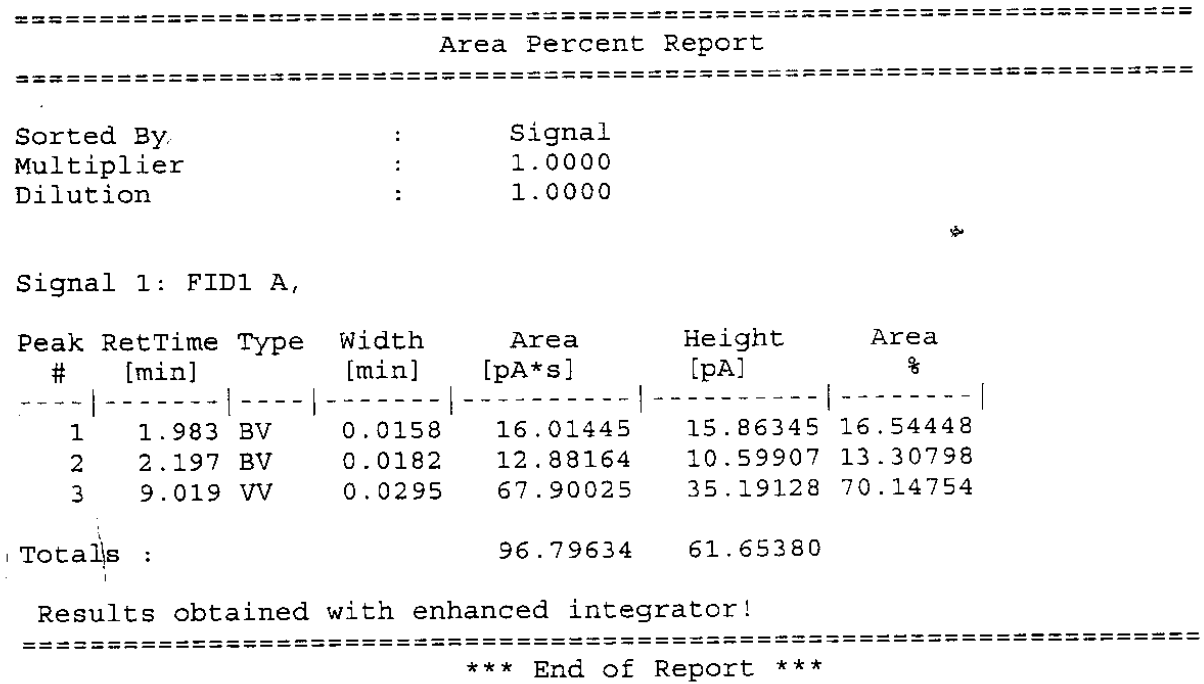




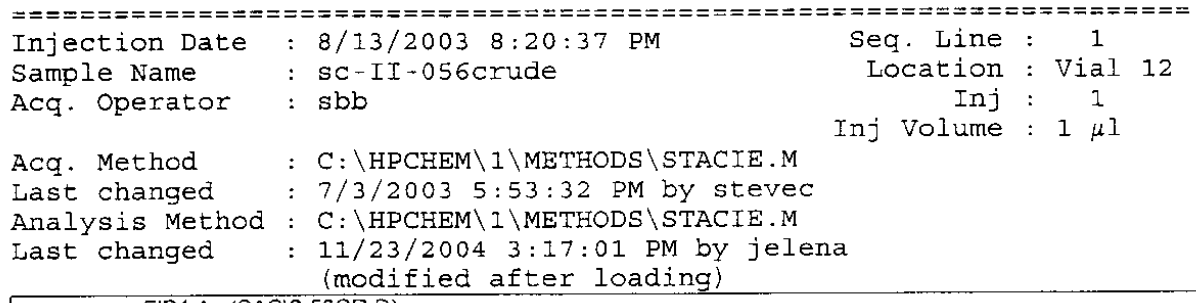

Acq. Method

$: C: \backslash$ HPCHEM $\backslash 1 \backslash M E T H O D S \backslash S T A C I E . M$

Last changed : 7/3/2003 5:53:32 PM by stevec

Analysis Method : C: $\backslash$ HPCHEM $\backslash I \backslash$ METHODS $\backslash S T A C I E . M$

Last changed : 11/23/2004 3:17:01 PM by jelena (modified after loading)
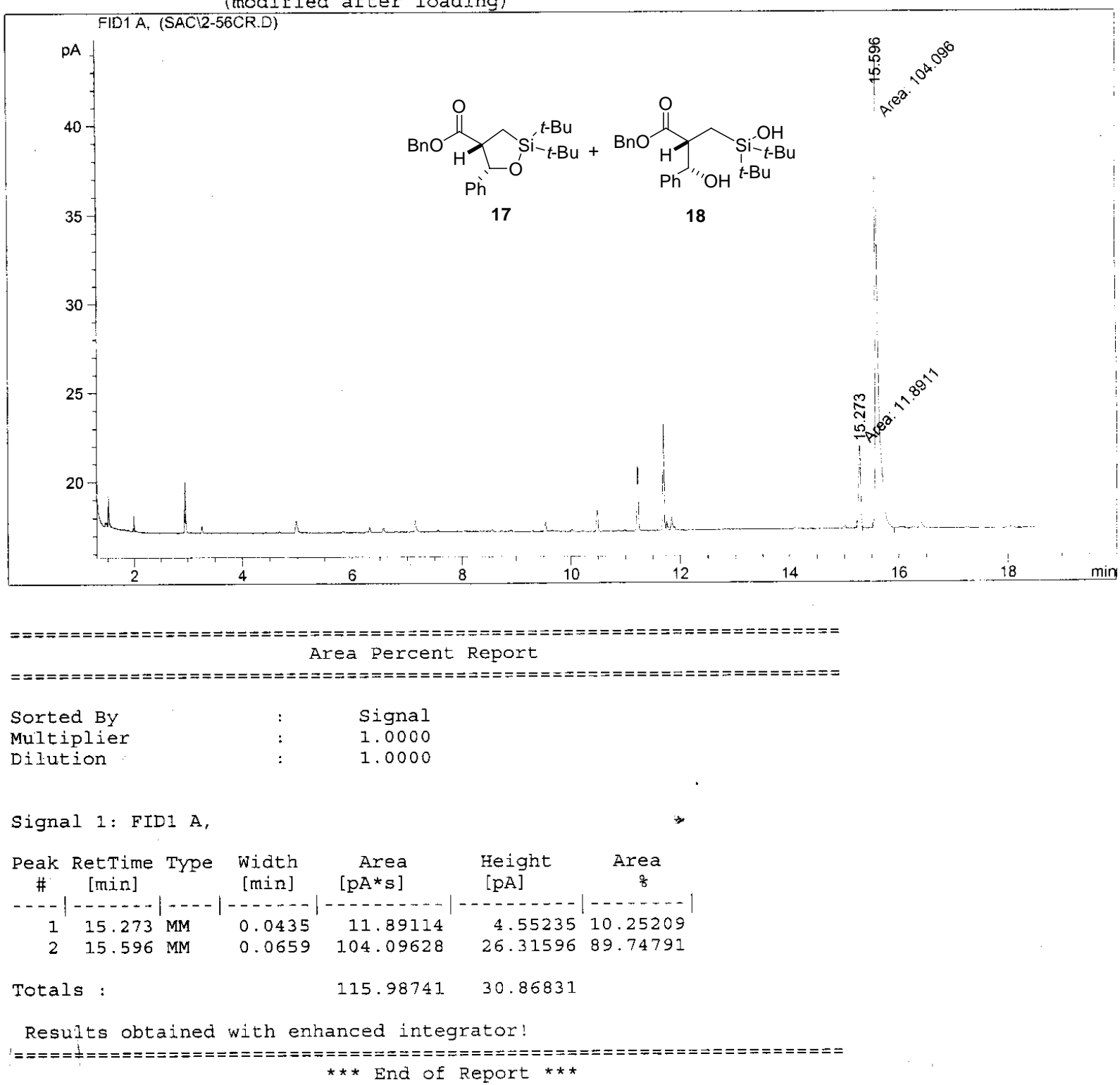


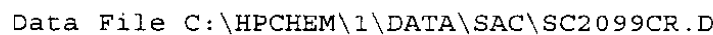
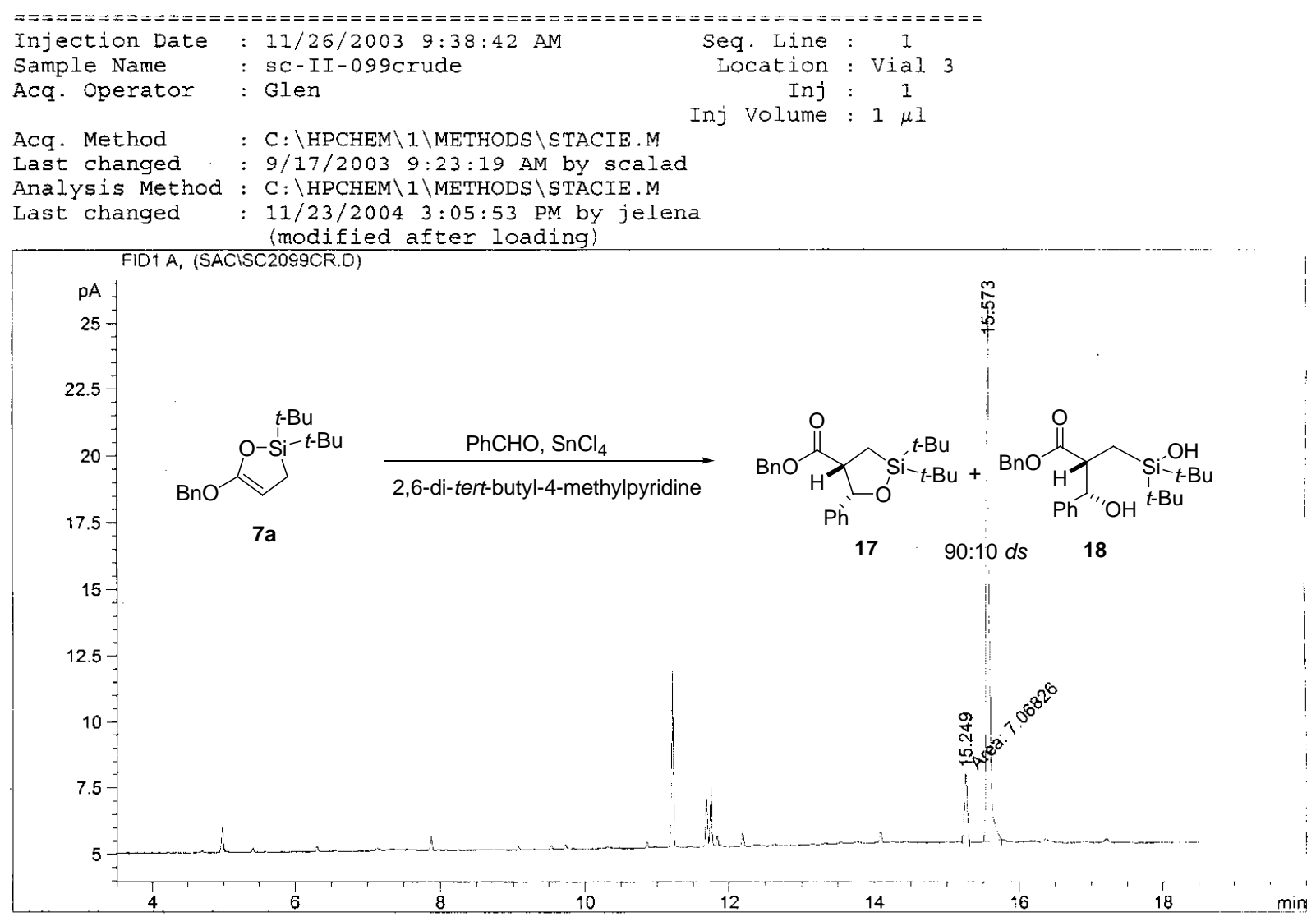

\begin{tabular}{|c|c|c|}
\hline sorted By & : & Signal \\
\hline Multiplier & : & 1.0000 \\
\hline Dilution & $:$ & 1.0000 \\
\hline
\end{tabular}

Signal 1: FID1 A,

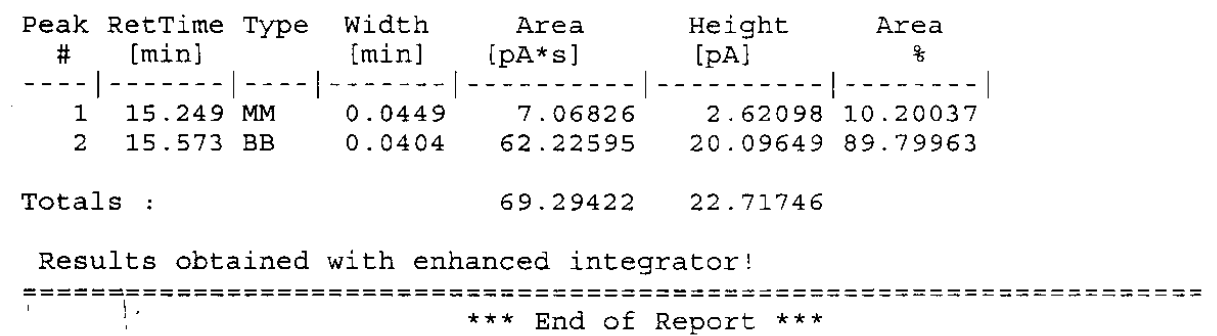


lata File $C: \backslash H P C H E M \backslash 1 \backslash D A T A \backslash S A C \backslash S C 2109 C R . D$
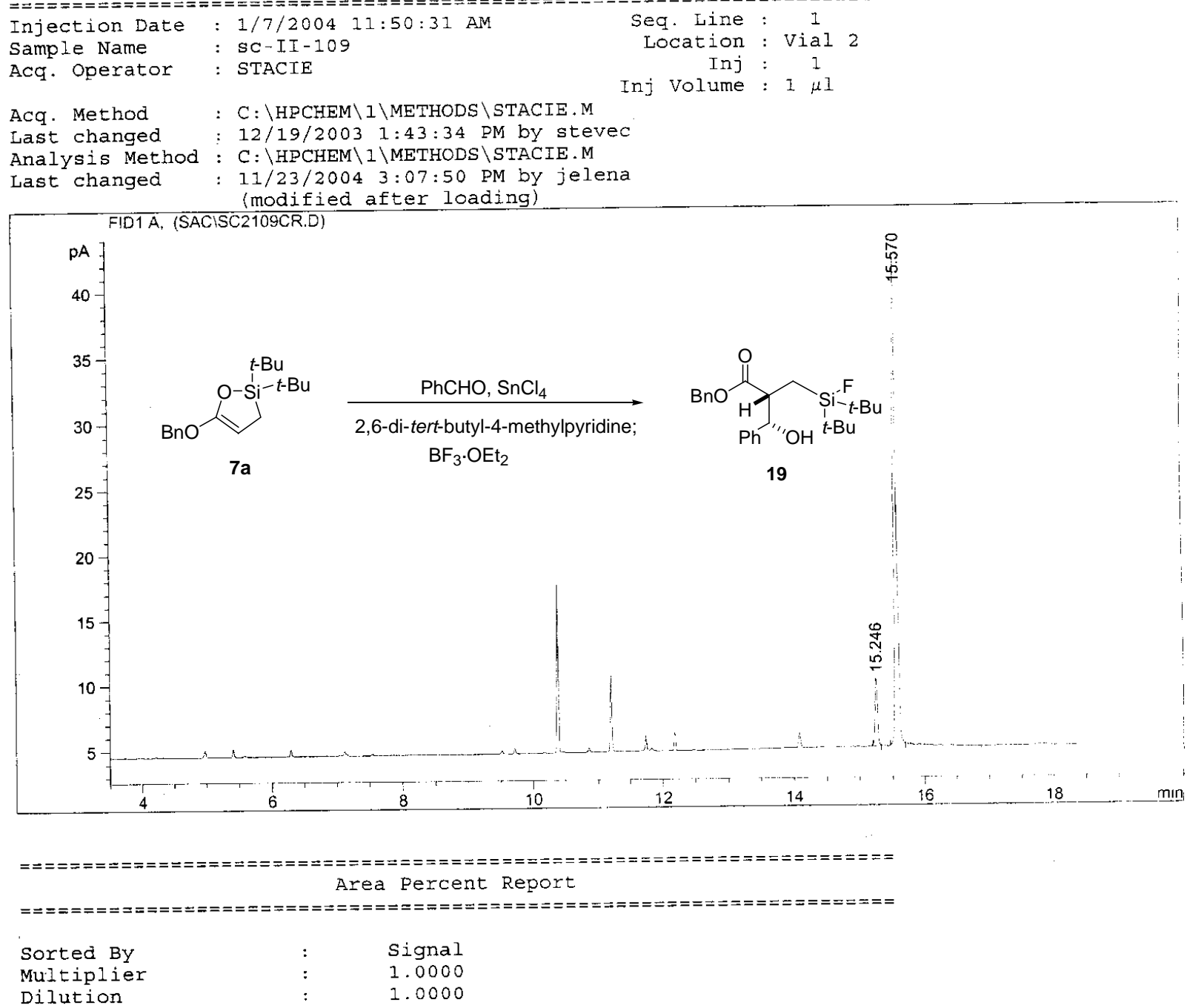

Signal 1: FIDI A,

\begin{tabular}{|c|c|c|c|c|c|c|}
\hline $\begin{array}{c}\text { Peak } \\
\#\end{array}$ & $\begin{array}{c}\text { RetTime } \\
\text { [min] }\end{array}$ & Type & $\begin{array}{c}\text { Width } \\
\text { [min] }\end{array}$ & $\begin{array}{r}\text { Area } \\
{\left[p A^{*} s\right]}\end{array}$ & $\begin{array}{l}\text { Height } \\
\text { [pA] }\end{array}$ & $\begin{array}{c}\text { Area } \\
\qquad \frac{q}{\sigma}\end{array}$ \\
\hline-- & $\ldots$ & & & -------- & & --1 \\
\hline 1 & 15.246 & BB & 0.0320 & 13.80317 & 5.18770 & 11.00751 \\
\hline 2 & 15.570 & $\mathrm{~PB}$ & 0.0360 & 111.59454 & 37.18347 & 88.99249 \\
\hline TC & : & & & 125.39771 & 42.37116 & \\
\hline
\end{tabular}

Results obtained with enhanced integrator!

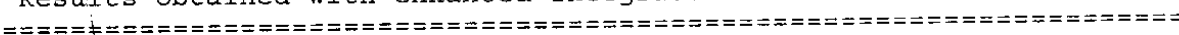

*** End of Report *** 